\title{
Malignant melanoma: modem black plague and genetic black box
}

\author{
Lynda Chin, ${ }^{1,2}$ Glenn Merlino, ${ }^{3,4}$ and Ronald A. DePinho ${ }^{2,4}$
}

Departments of ${ }^{1}$ Dermatology and ${ }^{2}$ Adult Oncology, Dana Farber Cancer Institute, Harvard Medical School, Boston, Massachusetts 02115 USA; ${ }^{3}$ Laboratory of M olecular Biology, N ational Cancer Institute, N ational Institutes of Health, Bethesda, M aryland 20892-4255 USA

References to 'black cancer' and 'fatal black tumors with metastasis' date to the writings of the legendary Greek physician Hippocrates in the fifth century B.C. However, it was not until the time of $\mathrm{N}$ apolean's Prussian $\mathrm{Cam}$ paign in 1806 that Renè Laennec, inventor of the stethoscope, provided the first description of melanoma as a disease entity in his presentation to the Faculté de M édecine in Paris (Bennett and Hall 1994). His 1812 manuscript reporting a case of disseminated melanoma also marks the first published use of the word 'melanoma' (Laennéc 1812). Several years later, a truly remarkable conceptual leap was made in the context of melanoma by a general practitioner William Norris ( $\mathrm{N}$ orris 1820) who arrived at the conclusion that melanoma is a hereditary disease. In his 1820 manuscript, N orris wrote: 'it is remarkable that this gentleman's father...died of a similar disease. This tumor...originated in a mole and it is al so worth mentioning that, not only my patient and his children had many moles..., but also his own father and brothers....These facts, together with a case that has come under my notice, rather similar, would incline me to believe that this disease is hereditary.' This prescient statement is all the more striking by the fact that it was made nearly half of a century before the genetic paradigm was articulated by Gregor Johann M endel in The Transactions of the Brunn Natural History Society in 1866 and 1869 (see Hecht 1989).

Today, cancer biologists stand resolute in the concept that melanoma has strong genetic underpinnings. This position has been strengthened by the identification of genomic hot spots (and their resident genes) in which structural alteration correlates with the genesis and/or progression of melanoma. More recent efforts to understand the biological impact of these melanoma-associated genetic lesions have yielded a series of scientific observations that has captured center stage in the fiel d of cancer genetics. These new molecular insights are indeed wel come because they come at a time when melanoma has emerged as a true health crisis. As a cancer type, incidence of melanoma is rising at a rate second

\footnotetext{
${ }^{4}$ Corresponding authors.

E-MAIL ron_depinho@dfci.harvard.edu; FAX (617) 632-6069.

E-MAIL gmerlino@helix.nih.gov; FAX (301) 480-7618.
}

only to lung cancer in women and, on its present course, the lifetime risk will reach 1 in 75 Caucasians in the US by the year 2000 (Rigel et al. 1996). In contrast to many other cancer types, it is notable that mel anoma affects a much younger population and is notorious for its propensity to metastasize early in the course of the disease and for its poor response to current therapeutic modalities (Herlyn 1993).

The purpose of this review is to provide a current view of the key genetic lesions associated with the development of melanoma including those involving the INK4a/ARF tumor suppressor locus, the ras family oncogenes, and the receptor tyrosine kinases and their ligands. These pathways in particular are emphasized here because their pathogenetic rol es in melanoma have been verified on several experimental levels. This review will not attempt to catalog the vast number of genetic and gene expression changes observed in melanoma; several comprehensive reports have capably summarized such information (Albino 1995; Greene 1997; Welch and Goldberg 1997; Haluska and Hodi 1998).

\section{Clinical aspects of melanoma}

Melanoma represents a collection of diseases as defined by pathological and clinical criteria. Histologically, the classification of melanoma reflects the location and/or depth of involvement (Fig. 1). For example, the in situ melanoma, characterized by the radial growth pattern, is confined primarily to the epidermis. In contrast, the 'vertical growth phase' of a malignant melanoma denotes a transition to a more aggressive and lethal condition, which is characterized by tumor invasion into the underlying dermis and subcutis, and often presages metastasis to distant sites. Although melanoma tends to spread to nonvisceral sites such as skin or lymph nodes, the most common visceral sites involved in metastatic melanomas are lung, liver, brain, bone, and small intestine (El der 1987).

The search for prognosticators of future metastatic disease and survival has been a major preoccupation of dermatopathologists. Among the many factors assessed, the total tumor thickness emerged as the best independent determinant of prognosis for nonmetastatic melanomas. 
Figure 1. Stages of histopathologic progression in melanocyte transformation. (A) N ormal skin. $\mathrm{N}$ ote the even distribution of dendritic melanocytes throughout the basal layer. (B) Benign proliferation of melanocytes. N evoid melanocytes are organized into uniform nests in a compound nevus. (C) Melanocyte dysplasia. Note the irregular and bridging nests consisting of large atypical melanocytes in a dysplastic nevus. (D) In situ melanoma, radial growth phase (RGP). $\mathrm{N}$ ote the single cells in upper layer of the epidermis (pagetoid spread). (E) Malignant melanoma, vertical growth phase (VGP).

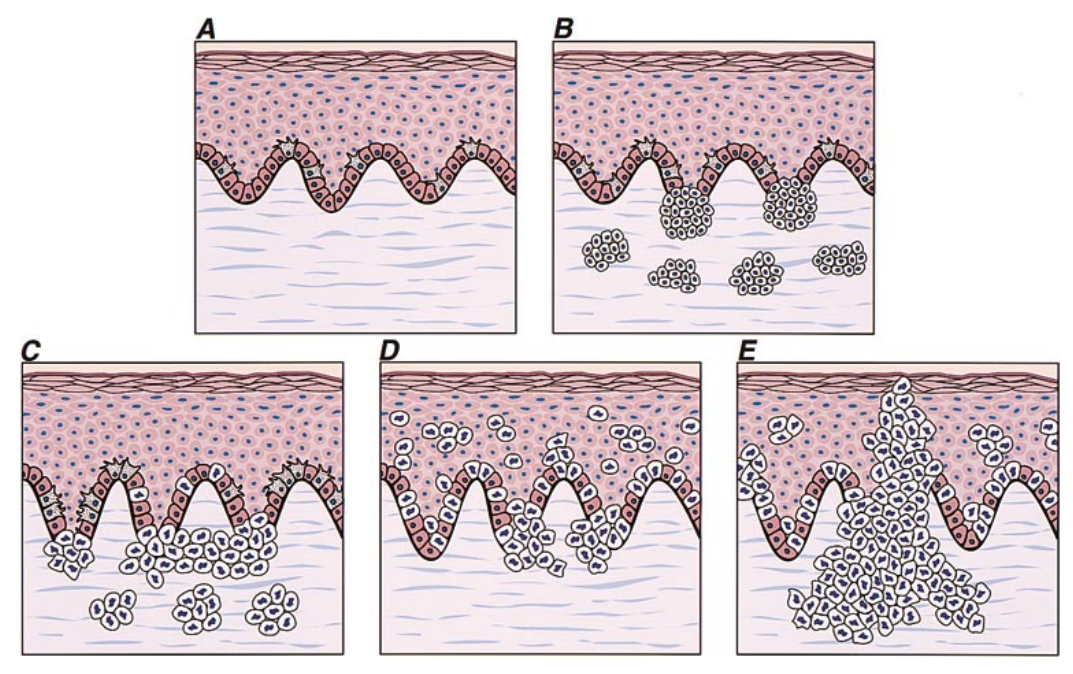

The system described by Breslow, which measures tumor thickness from the uppermost nucl eated layer of the epidermis (i.e., the granular cell layer) to the greatest depth of tumor invasion, has gained acceptance as the classification system of choice as a result of its ease, reproducibility, and objectivity. By comparison, Clark's classification system correlates anatomic level of invasion (Fig. 2), coupled with mitotic index, to prognosis. This system, al though it offers more information, can be more cumbersome and may lack reproducibility (for review, see Barnhill et al. 1993).

Despite the long history of clinical recognition and the enormous efforts in pathological classification, the precise pathogenetic mechani sms leading to melanoma still are not well understood. Several features of this disease have provided evidence for genetic and epigenetic etiologies. For example, the contribution of sun exposure to the risk of developing melanoma appears firmly accepted, al though the precise mode of exposure (e.g., intermittent intense exposure vs. chronic exposure) associated with increased risk has not been defined. It is al so clear that skin color is an important modifier of melanoma risk. Dark-skinned indi viduals have substantially lower risks of melanoma incidence than fair-skinned populations given the same levels of UV exposure (Barnhill et al. 1993). Together, the fact that solar radiation increases the risk for melanoma in some, and that the magnitude of this effect is modifiable by a known heritable factor, that is, skin type, suggest that identifiable genetic predisposing factors exist for melanomagenesis.

Other evidence supporting a genetic predisposition is the fact that $10 \%$ of melanoma patients have a history of an affected family member. In some kindreds, melanomas occur in the setting of the familial atypical multiple mole and melanoma (FAMM M) syndrome, also known as the dysplastic nevus syndrome (DNS). Members of these affected kindreds develop a large number of atypical moles or dysplastic nevi early in life and they succumb to overt melanoma with a higher penetrance and earlier onset than sporadic melanoma (for review, see Haluska and Hodi 1998).

Although the precise definition of dysplastic nevus is still controversial, most dermatologists agree that the density of dysplastic nevi correlates with melanoma risk in a patient (Tucker et al. 1997). Some evidence even suggest that dysplastic nevi are not only markers of risk but al so a potential precursor. These include the observations that many superficial spreading melanomas, the most common subtype (Table 1 ), are associated with preexisting nevi, and that approximately one-third of these melanomas are associated with nevus remnants with atypical features (for review, see Rhodes 1993). More-
Figure 2. Pathological classification of melanoma. Breslow thickness measures the absolute thickness of the melanoma from the most superficial nucleated layer, granular layer, to the deepest level of invasion. This measurement has strong predictive value in the prognosis of patients with non-metastatic melanomas. The Clark's classification system correl ates prognosis to the anatomic level of involvement.
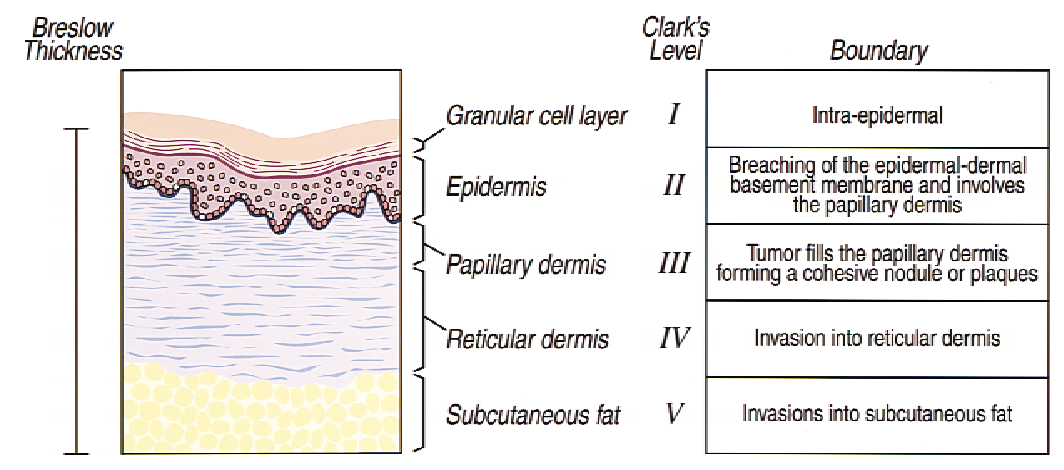
Table 1. Clinical classification of melanomas

\begin{tabular}{|c|c|c|c|c|c|}
\hline Subtype & Frequency & $\begin{array}{l}\text { Common } \\
\text { sites }\end{array}$ & $\begin{array}{c}\text { Median age } \\
\text { of diagnosis (years) }\end{array}$ & $\begin{array}{l}\text { Duration } \\
\text { of RGP }\end{array}$ & Others \\
\hline $\begin{array}{l}\text { Superficial spreading } \\
\text { melanoma }\end{array}$ & $70 \%$ & $\begin{array}{l}\text { trunk of men; } \\
\text { legs of women }\end{array}$ & 44 & $1-5$ years & $\begin{array}{l}\text { potential precursor lesion } \\
=\text { dysplastic nevus }\end{array}$ \\
\hline N odular melanoma & $10 \%-30 \%$ & $\begin{array}{l}\text { trunk of men; } \\
\text { legs of women }\end{array}$ & 53 & 6-18 months & \\
\hline $\begin{array}{l}\text { Acral lentiginous } \\
\text { melanoma }\end{array}$ & $\begin{array}{l}\text { most common in } \\
\text { darker skin } \\
\text { types }\end{array}$ & palms; soles; nails & 65 & 3 years & \\
\hline $\begin{array}{l}\text { Lentigo maligna } \\
\text { melanoma }\end{array}$ & $<5 \%$ & $\begin{array}{l}\text { sun-damaged skin of } \\
\text { head and neck }\end{array}$ & 65 & 3-15 years & $\begin{array}{l}\text { precursor lesion =lentigo } \\
\text { maligna }\end{array}$ \\
\hline
\end{tabular}

over, among the subset of familial melanomas, $>70 \%$ of the primary melanomas are associated with pre-existing dysplastic nevi (Greene et al. 1985). In a series of studies on melanoma-prone kindred cohort, it was shown that almost all of the family members with cutaneous melanoma al so had dysplastic nevi, and only members with dysplastic nevi developed new melanoma during the period of follow-up (Greene et al. 1985). These clinical observations strongly implicate the dysplastic nevus as a precursor lesion, much as the relationship described for colonic polyps and colorectal carcinoma (Kinzler and Vogel stein 1996). The search for linked loci responsible for melanoma predisposition has yielded some promising candidates. Table 2 summarizes some of these chromosomal lesions and in the review that follows, we discuss those loci experimentally proven to be involved in the genesis and progression of melanoma.

\section{Loss of the 9p21 tumor suppressor-sine qua non of melanomagenesis}

The familial melanoma locus at 9p21

Several years ago, a series of cytogenetic, linkage, and molecular analyses of familial and sporadic melanomas provided compelling evidence that loss of a tumor suppressor residing at 9p21 represents a rite of passage for virtually all melanomas. The ensuing detailed molecular analysis of this locus has resulted in one of the most intriguing stories in cancer biology today.

The 9p21 locus in man, and the syntenic region on mouse chromosome 4, contains the closely linked INK4a and INK4b genes whose products, p16 IN K4a (MST1/CDKN2) and $\mathrm{p} 15^{\mathrm{IN} \mathrm{K4b}}$, act as negative regulators of the cell cycle (Kamb 1995). These genes are members of the IN K4 (inhibitor of the cyclin-dependent kinase 4) family, which also include $\mathrm{p} 18^{\mathrm{INK} 4 \mathrm{c}}$ and $\overline{\mathrm{p}} 19^{\mathrm{INK} \overline{4} \mathrm{~d}}$ (Harper and El ledge 1996). On the mol ecular level, IN K4 family members execute their growth arrest activities through interaction with and inhibition of the G1 cyclindependent kinases, CDK4 and CDK6. CDK4/6 play prominent roles in the phosphorylation of the retinoblastoma tumor suppressor gene product, $\mathrm{pRb}$, the major gatekeeper of the cell-cycle restriction point. Left in its hypophosphorylated state, the pRb protein constrains cell-cycle growth through its active transcriptional repression of genes required for exit from the resting $G_{1}$ phase and progression through the DNA synthetic (S) phase of the cell cycle (Fig. 3) (for review, see Sherr 1996). Loss of p16 ${ }^{\mathrm{INK} 4 \mathrm{a}}$ function tips CDK4/6 towards a more highly activated state, resulting in pRb hyperphosphorylation with associated derepression of pRb-regulated genes and unscheduled entry into $S$ phase.

Interest in the $\mathrm{p} 16^{\mathrm{IN} \mathrm{K4a}}$ gene reached a new high with

Table 2. Chromosomal alterations in cutaneous malignant melanoma

\begin{tabular}{|c|c|c|c|c|}
\hline Chr & Alterations & $\begin{array}{l}\text { Candidate } \\
\text { genes }\end{array}$ & Involvement & Reference \\
\hline $1 \mathrm{p}$ & $\begin{array}{l}\text { Deletion; translocation; } \\
\text { LOH }\end{array}$ & & $\begin{array}{l}\text { LOH in advanced melanomas; Chr } 1 \\
\text { transfer } \rightarrow \text { suppresses metastasis, } \\
\text { but not tumorigenicity, of M elJuSo }\end{array}$ & $\begin{array}{l}\text { see, e.g., Miele et al. (1996); } \\
\text { Dracopoli et al. (1998) }\end{array}$ \\
\hline $6 q 22-27$ & Deletion most common & & $\begin{array}{l}40 \%-75 \% \text { LOH in late stage } \\
\text { melanomas; Chr } 6 \text { transfer } \rightarrow \\
\text { conflicting results regarding } \\
\text { tumorigenicity vs. metastasis in } \\
\text { different cell lines }\end{array}$ & $\begin{array}{l}\text { for review, see Trent et al. } \\
\text { (1990); Welch et al. (1994); } \\
\text { Miele et al. (1996); Welch and } \\
\text { Goldberg (1998) }\end{array}$ \\
\hline 7 & Amplification & EGFR & $\begin{array}{l}\text { Increased expression in melanomas; } \\
\text { level correlates with aggressiveness }\end{array}$ & $\begin{array}{l}\text { Koprowski et al. (1985); de Wit } \\
\text { et al. (1992a,b) }\end{array}$ \\
\hline $9 p 21$ & $\begin{array}{l}\mathrm{LOH} \text {; del etion; } \\
\text { intragenic mutation }\end{array}$ & INK4a & $\begin{array}{l}\text { dysplastic nevus; early melanoma; } \\
\text { hereditary predisposition }\end{array}$ & see text \\
\hline 10q24-26 & $\mathrm{LOH}$ & $\begin{array}{l}\text { MXI1; PTEN/ } \\
\text { MMAC1 }\end{array}$ & dysplastic nevus; early melanoma & see text \\
\hline
\end{tabular}




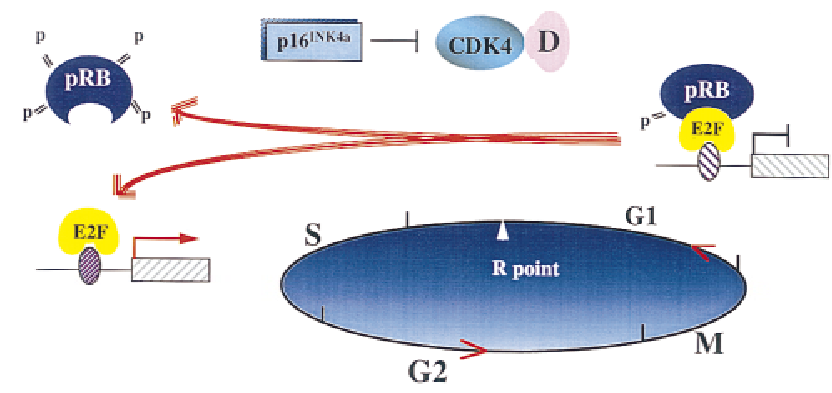

Figure 3. The RB-regulated G1/S transition the mammalian cell cycle. In $\mathrm{G}_{1}$, hypophosphorylated Rb binds the E2F transcription factor, resulting in transcriptional repression of E2Fresponsive genes. In response to growth promoting signals, the CDK4/cyclin D complex participates in the phosphorylation of $\mathrm{pRB}$, causing release of $\mathrm{pRB}$ from promoter-bound E2F, activation of E2F-responsive genes, and subsequent entry into $S$ phase. The kinase activity of CDK4/cyclin D is negatively regulated by $\mathrm{p} 16^{\mathrm{INK} 4 \mathrm{a}}$, a member of the INK4 G1-specific cyclin-dependent kinase inhibitor (CKI) family.

the seminal discovery of a second unrelated non-CKI protein, encoded by an INK4a locus reading frame distinct from that of p16 ${ }^{\text {IN K } 4 a}$ (Quelle et al. 1995). This new reading frame initiates in a different first exon (exon $1 \beta$ ) and continues in an alternative reading frame in the shared exon 2 (Fig. 4). The novel protein was named $\mathrm{p} 19^{\mathrm{ARF}}$ for al ternative reading frame protein and, to denote the fact that the INK4a gene encodes two distinct products, it is now referred to as the INK4a/ARF locus.

p19ARF functions as a potent growth suppressor as evidenced by its ability to induce $\mathrm{a} G 1$ and $\mathrm{G} 2$ phase arrest (Quelle et al. 1995, 1997), block oncogenic transformation, and enhance apoptosis (Pomerantz et al. 1998). Most important is the finding that these $\mathrm{p} 19^{\mathrm{ARF}}$ activities require p53 (Kamijo et al. 1997; Pomerantz et al. 1998; Stott et al. 1998; Zhang et al. 1998), thus linking a single locus to both of pRb (p16 $\left.6^{\mathrm{INK} 4 \mathrm{a}}\right)$ and $\mathrm{p} 53\left(\mathrm{p} 19^{\mathrm{ARF}}\right)$. The biochemical basis for the p53 dependency of p19ARF functions appears to relate to the ability of p19ARF to bind $\mathrm{Mdm} 2$, block $\mathrm{Mdm} 2$-induced degradation of p53, and stabilize p53 protein (Kamijo et al. 1998; Pomerantz et al. 1998; Stott et al. 1998; Zhang et al. 1998). Although not evolutionarily conserved, the mouse $\mathrm{p} 19^{\mathrm{ARF}}$ protein has also been shown to bind p53 directly in the absence of $\mathrm{Mdm} 2$ (Kamijo et al. 1998), suggesting an additional Mdm2-independent mechanism for p19ARF function. Moreover, the observation that $\mathrm{p} 19^{\mathrm{ARF}}$ levels are elevated in p53-deficient cells (Quelle et al. 1995; Stott et al. 1998) had raised the possibility that there existed a regulatory feedback loop between ARF and p53 on the level of gene expression. Consistent with this view is the finding that p53 itself can down-regulate expression of p19ARF (Stott et al. 1998), possibly through repression of the $1 \beta$ promotor.

In melanoma, as well as other 9p21-associated cancers, the 9p21 region most commonly sustains homozygous deletions in sporadic cases (see references in Funk et al. 1998; Haluska and Hodi 1998; Kumar et al. 1998; Mat- sumura et al. 1998; Ruiz et al. 1998; Wagner et al. 1998) and both deletions and point mutations in familial cases (Hussusian et al. 1994; Kamb et al. 1994; Gruis et al. 1995; Fitzgerald et al. 1996; Flores et al. 1998; MacKie et al. 1998; Platz et al. 1998; Soufir et al. 1998) often eliminating INK4b and INK4a/ARF (for review, see Chin et al. 1998; Hal uska and Hodi 1998). The high incidence of deletion has fueled an ongoing debate centered on whether each of these genes contributes to the tumor suppressor activity encoded within 9p21. With respect to p16 $6^{\mathrm{INK} 4 a}$, its designation as a suppressor of human neoplasia appears to be concl usive. M ost convincing are reports describing germl ine mutations that inactivated the p16 $6^{\mathrm{IN} \mathrm{K} 4 \mathrm{a}}$ specific exon $1 \alpha$ in familial mel anoma (Hussussian et al. 1994; FitzGerald et al. 1996). Many other melanoma-associated mutations affecting the p16 ${ }^{\text {IN K 4a }}$ reading frame have since been described and the majority of these mutations target the ankyrin repeat region of p16 ${ }^{\text {IN K4a }}$ (Hussussian et al. 1994; Kamb et al. 1994; Liu et al. 1995), a domain known to play a role in CDK4/6 interaction (Serrano et al. 1993; Brotherton et al. 1998; Russo et al. 1998). That the p16 iN K4a_CDK4 rel ati onship is indeed relevant to melanoma is further supported by the identification of germline CDK4 mutations in two melanoma-prone families (Zuo et al. 1996; Soufir et al. 1998). This mutation disrupts the p16 $6^{\text {IN K } 4 a}$ interaction domain, thereby rendering CDK 4 refractory to inhibition by the IN K 4 proteins (Wolfel et al. 1995). Finally, in addition to gene deletion and point mutations, loss of p16 ${ }^{\text {IN K } 4 a}$ function can result from methylation-induced transcriptional silencing (Gonzalez-Zulueta et al. 1995; Kamb 1995), al though this mode of inactivation does not appear to be common in melanoma (Gonzalgo et al. 1997).

Unlike the case for $\mathrm{p} 16^{\mathrm{IN} K 4 \mathrm{a}}$, definitive data linking $\mathrm{p} 15^{1 \mathrm{~N} \mathrm{~K} 4 \mathrm{~b}}$ to $9 \mathrm{p} 21$-associated cancers have yet to emerge. For example, there are no reports of mutations exclusively targeting the $\mathrm{p} 15^{\mathrm{IN} \mathrm{K} 4 \mathrm{~b}}$ open reading frame in human cancers. Furthermore, it is notable that $\mathrm{p} 15^{1 \mathrm{~N} \mathrm{~K} 4 \mathrm{~b}_{-}}$ deficient mice exhibit an extremely weak cancer-prone phenotype ( $E$. Latres and M. Barbacid, pers. comm.). In contrast, the case of $\mathrm{p}^{\mathrm{A} 9^{\mathrm{ARF}}}$ as a tumor suppressor in humans appears to be a stronger, al beit inconclusive, one. The strongest existing evidence includes identification of mutations or deletions impacting exclusively on the p19ARF $1 \beta$ exon in some T-ALL cases (Gardie et al. 1998). However, germline $\mathrm{p} 19^{\mathrm{ARF}}$-specific mutations have yet to be reported in humans, and most tumor samples harboring p19ARF loss show concomitant deletion or mutation of $\mathrm{p} 16^{1 \mathrm{~N} \mathrm{~K} 4 \mathrm{a}}$ and/or $\mathrm{p} 15^{1 \mathrm{NK} 4 \mathrm{~b}}$ sequences (for review, see Chin et al. 1998). N everthel ess, a p19ARF specific knockout in the mouse generates a strong cancer-prone condition (Kamijo et al. 1997) and p19ARF overexpression can suppress M yc/Ras transformation in cell culture (Pomerantz et al. 1998). These organismal and cell culture studies indicate that p19ARF possesses potent tumor suppressor activity, thus el evating the likelihood that its ortholog, p14 ${ }^{\mathrm{ARF}}$, serves a similar role in human tumors. Given the high frequency of dual inactivation of $\mathrm{p} 19^{\mathrm{ARF}}$ and an IN K4 family member in hu- 


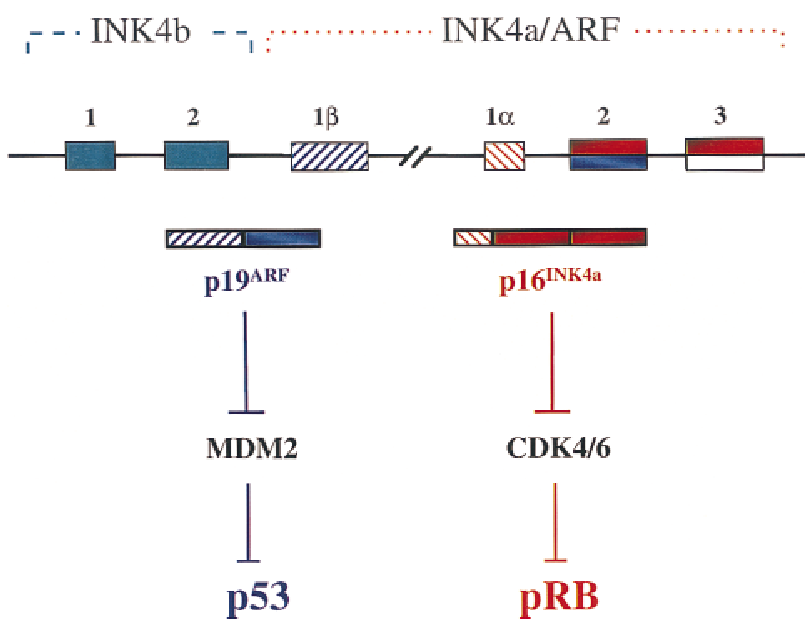

Figure 4. The $9 p 21$ genomic locus. Within a relatively short genomic distance, the 9p21 locus (and its syntenic region in mouse) encodes for three negative regulators of the cell cycle: p15 IN K4b, $\mathrm{p} 16^{\mathrm{INK} 4 \mathrm{a}}$, and p19ARF. The INK4b gene encodes for p15 INK4b, also a $G_{1}$-specific CKI, similar to p16 $6^{\text {INK4a }}$. The INK4a/ARF gene utilizes al ternative first exons and common downstream exons to encode two distinct products. The exon $1 \alpha$ bearing transcript encodes p16 IN K4a,$a \mathrm{G}_{1}$-specific CKI (see Fig. 3). The exon $1 \beta$ bearing transcript encodes p19ARF. p19ARF neutral izes $\mathrm{M} \mathrm{dm} 2$, thereby stabilizing p53 levels and enhancing p53 activity (see text). Thus, the INK4a/ARF Iocus encodes two proteins functioning upstream of both the $R b$ and $p 53$ pathways.

man cancers, it is tempting to speculate that the stringent antitumor mechanisms of humans (relative to those in mice) may necessitate dysregulation of both $\mathrm{Rb}$ and p53 tumor suppressor pathways for efficient transformation.

The unique genomic organization of IN K4a/ARF may help explain why IN K4a/ARF is a frequent target of tumorigenesis, in that a single genetic hit would result in the simultaneous disruption of these two key antioncogenic mechanisms. On a related note, the placement of p19ARF al ong the p53 pathway (Kamijo et al. 1997, 1998; Pomerantz et al. 1998; Stott et al. 1998; Zhang et al. 1998) and its role as an 'enhancer' of p53 activity may also account for the very low incidence of p53 mutations in melanoma (for review, see Chin et al. 1998). An absence of p53 mutations al so holds true in a mouse model for melanoma generated in the IN K4a/ARF-deficient background (see bel ow) (Chin et al. 1997). This observation led us to propose that p19ARF inactivation would lessen the genetic requirement for loss of p53 itself in melanoma (Chin et al. 1997), a reciprocal relationship analogous to the observation that sarcomas harboring MDM2 amplification do not harbor p53 mutations (Oliner et al. 1992). The tight functional inter-relationship of p19ARF and p53 is al so supported by the observation that deletion of p19ARF or p53 are common, but mutual ly excl usive, events during the process of cellular immortalization in mouse fibroblasts (Kamijo et al. 1997).

The lack of deletions/mutations in both INK4/ARF and p53 in the same human cancers al so appears to extend to other types of carcinomas. A revisited mutation analysis has been performed by Pomerantz et al. (1998) for carcinomas of the bladder, oral region, and lung and for lymphoid neoplasms, such as B-cell chronic lymphocytic leukemia and Hodgkin's and N on-Hodgkin's Iymphomas (Gruis et al. 1995; N ewcomb et al. 1995; Breenner et al. 1996; Hangaishi et al . 1996; Heinzel et al. 1996; Kinoshita et al. 1996). In >500 tumors analyzed, the mutation rates were $18 \%$ for $\mathrm{p} 16^{\mathrm{IN} \mathrm{K} 4 \mathrm{a}}, 14 \%$ for $\mathrm{p} 53$, and $4 \%$ for both. INK4a point mutations that result in a single amino acid change in the $\mathrm{p} 16^{\mathrm{IN} K 4 a}$ ORF were reanalyzed to determine the genetic status of the p19ARF ORF. Only nine $(<2 \%)$ of 405 eval uable cases harbored both p53 and p19ARF mutations. Because all nine cases also had alteration in $\mathrm{p} 16^{\mathrm{IN} \mathrm{K} 4 a}$, it remains possible that $\mathrm{p} 19^{\mathrm{ARF}}$ mutation was incidental to that of $\mathrm{p} 16^{\mathrm{INK} 4 \mathrm{a}}$ in those tumors. In fact, the most common point mutation in the p19ARF ORF (a P93L substitution; Quelle et al. 1995b) has been shown to be fully active in cell-cycle arrest (Quel le et al. 1997) and in suppression of Myc/Ras tranformation and in stabilizing p53 in the presence of high $\mathrm{Mdm} 2$ levels (Pomerantz et al . 1998). The distincly uncommon occurrence of co-mutation of p53 and p19 ${ }^{\mathrm{ARF}}$ lends support to the widely held view that they operate through a common tumor suppressor pathway.

Interestingly, despite the strong link between IN K4a/ ARF and melanoma in humans, mice doubly null for p16 ${ }^{\text {IN K } 4 a}$ and ARF (exon $2+3$ deletion) failed to develop melanoma (Serrano et al. 1996). Rather, the most common malignancies encountered in this model were fibrosarcomas and B-cell Iymphomas-two cancer types that also arise in humans inheriting a defective copy of the INK4a gene (Cordon-Cardo 1995). Among the possible explanations for the lack of melanoma in the INK4a/ ARF-null mice is the need for cooperating genetic le sions; one likely candi date consi dered early in the course of these studies was activation of the Ras pathway. This view stemmed from the ability of Ras to elicit two very different cellular responses-sensecence or transformation-in the presence or absence of intact INK4a/ARF function, respectively (Serrano et al. 1997). The lack of Ras-induced transformation in the presence of intact mortality pathways is consistent with an earlier transgenic mouse study showing that melanocytic expression of activated $\mathrm{H}-\mathrm{Ras}^{\mathrm{val}} 12$ did not result in melanocytic transformation (Powell et al. 1995). In this particular Ras model, metastatic melanoma is observed only following exposure to the carcinogen DMBA (Gause et al. 1997). These results imply that, al though Ras activation may play an etiological role in melanoma, other cooperative genetic lesions are clearly required.

\section{Pathogenetic role for activated ras in melanoma?}

Historically, activating ras mutations have been among the most common proto-oncogene mutations in human cancers. Despite its prominence in many other cancer types, early studies attempting to establish a causal role for activated Ras in melanoma generated conflicting re- 
sults. For example, stable transfection of activated $\mathrm{H}$-ras into cultured mouse (Wilson et al. 1989; Ramon y Cajal et al. 1991) and human (Albino et al. 1992) melanocytes was shown to induce phenotypic characteristics of fully transformed melanoma cells, such as growth inhibition by protein kinase $\mathrm{C}$ activator, anchorage independence, tumorigenicity in nude mice, and chromosomal instability. The status of IN K4a/ARF was not examined in these cultures. On the other hand, Albino et al . (1989) reported that the frequency of activating ras mutations (predominantly $\mathrm{N}$-ras) was significantly higher in cultured melanoma cell lines $(24 \%)$ than in noncultured melanomas (5\%-6\%). This observation raised the possibility that ras mutations may be a consequence of the inherent genomic instability of transformed cells further accentuated by adaptation to culture. By contrast, Van't Veer et al . (1989) has observed a frequency of N-ras mutations in primary melanomas approaching $20 \%$. Other groups have detected a higher frequency of ras mutations ( $\mathrm{N}$-ras more than $\mathrm{H}$-ras) in metastatic and recurrent melanomas (Ball et al. 1994; Jafari et al. 1995; Wagner et al. 1995), suggesting a role for Ras activation in disease progression rather than initiation. These data correl ate well with expression studies showing increased Ras immunoreactivity in late stage melanoma (Y asuda et al. 1989). In addition, activating $\mathrm{N}$-ras and $\mathrm{H}$-ras mutations have been documented in metastatic melanoma cell lines through use of the N IH/ 3T 3 transformation assay (Albino et al . 1984). Taken together, the consensus view would favor a role for $\mathrm{N}$-ras and $\mathrm{H}$-ras mutations in promoting progression toward a more advanced stage of melanoma.

In an effort to obtain formal genetic proof in support for this Ras hypothesis, a transgenic mouse model was generated in which activated Ras was expressed in the melanocytes of the IN K4a/ARF null mouse. Against the wild-type INK4a/ARF background, spontaneous cutaneous melanomas emerged at a very low incidence and with a long latency (Chin et al . 1997). Signficantly, these rare melanomas showed spontaneous deletion of both alleles of INK4a/ARF. Correspondingly, melanomas arising in INK4a/ARF heterozygotes sustained a consistent loss of the remaining wild-type INK4a/ARF allele. Finally, on an INK4a/ARF ${ }^{-1}$ - background, these transgenic animals developed spontaneous cutaneous melanomas with high penetrance after a short latency (Chin et al. 1997). Therefore, Ras activation can cooperate with IN K4a/ARF deficiency in vivo to accelerate the genesis of melanoma. Lastly, as mentioned above, similar to human melanoma, the p53 gene remained in a wild-type configuration in these mouse melanomas (Chin et al. 1997). Thus, the Ras-IN K4a/ ARF mouse mel anoma profile recapi tulates some of the prominent genetic features observed in human melanoma, namely activation of the Ras pathway, deletion of the INK4a/ARF tumor suppressor, and absence of p53 mutation. However, despite these similarities, a curious distinction of the mouse Ras/INK/ARF ${ }^{-1-}$ model is its lack of metastasis. This difference is intriguing given the presumed role for Ras activation in promoting invasive and metastatic behavior in a number of cell culture-based experiments (see above). Together, these data suggest that activation of the Ras pathway, while necessary for metastatic activity, may be not sufficient to induce this hall mark feature of melanoma. Such findings have directed attention to other signaling pathways, particularly those linked to a class of transmembrane receptors known collectively as receptor tyrosine kinases (RTKs).

\section{RTKs in the normal and neoplastic melanocyte}

RTKs play pivotal roles in the regulation of virtually all basic cellular processes, including proliferation, differentiation, migration, and survival. RTKs are transmembrane polypeptides containing both an extracellular ligand-binding domain and a cytoplasmic tyrosine kinase domain that signals to a number of pathways including the Ras/MAPK pathway, phosphatidylinositol 3-kinase (PI3-K), among others. An understanding of how RTKs and their signaling pathways influence the behavior of transformed melanocytes has advanced significantly through a series of transgenic experiments comparing the consequences of Ras activation (see above) versus activation of pathways at the level of the receptor (see below). In addition to these cancer studies, much has been gained from the study of normal melanocyte development, particularly in various mouse mutants with pigmentation defects. Thus, to better frame the RTK-cancer connection, we will begin with a brief review of the role of RTKs in normal melanocyte biology.

\section{RTKs in normal melanocyte development}

Melanocytes of the integument, choroid, and ear originate from the neural crest, a transi ent embryonic structure derived from the dorsal neural tube. When appropriately instructed, a subpopulation of neural crest cells undergo epithelial/mesenchymal conversion, migrate lateral ly bel ow the epi dermis, and ultimately give rise to skin and ear melanocytes (Le Douarin 1982; Bennett 1993). It is now appreciated that this developmental process is tightly regulated through the orchestrated activities of multiple and perhaps sequential RTKs (see below). The essential roles of RTKs in normal melanocyte development have been demonstrated through the analyses of a variety of pigmentation defects, particularly piebaldism.

Piebaldism is a condition characterized clinically by patches of white skin and hair. Within these vitiligi nous areas, there is a complete absence of melanocytes as a result of aberrant migration and survival. Spontaneous coat color mutations mapping to either the dominant white spotting (W) locus or the steel (SI) locus have long been known to cause piebaldism in homozygous mice (for review, see Bennett 1993). The coat color gene at the W locus was later determined to be c-kit, a proto-oncogene encoding a RTK (Chabot et al. 1988; Geissler et al. 1988), and that at the SI locus to code for its ligand, the steel or mast cell growth factor SLF (reported by several laboratories; for review, see Witte 1990). SLF-Kit signaling appears to be required for functions such as lateral migration and survival of murine melanocyte precursors 
in vivo (N ishikawa et al. 1991; Steel et al. 1992; WehrleHaller and Weston 1995; Kunisada et al. 1998). The relevance of this pathway to human melanocyte development has been established by identification of c-kit mutations in piebald patients (Fleischman et al. 1991; Giebel and Spritz 1991).

Other RTKs are involved in murine mel anocyte devel opment as well. For example, the patch (Ph) gene, which encodes the platelet-derived growth factor receptor $\alpha$ (PDGFR $\alpha$ ), is al so associated with white spotting in mice (Stephenson et al. 1991; Soriano 1997). More recently, analysis of mel anocyte precursors in transgenic mice expressing hepatocyte growth factor/scatter factor (HGF/ SF) has implicated its RTK, c-met (Bottaro et al. 1991; $\mathrm{N}$ aldini et al. 1991), in melanoblast survival, differentiation, and/or migration (Takayama et al. 1996; Kos et al. 1998).

The growing number of RTKs implicated in melanocyte development may reflect their unique and cooperative roles in normal melanocyte biology. This view is supported by experimental analysis of normal melanocyte growth and differentiation in cultures. Unlike many cell types, human melanocytes absolutely require growth factor supplementation for survival and growth in vitro. Several growth factors have been identified that stimulate mitogenesis through RTKs expressed in melanocytes, including SLF, HGF/SF, and basic fibroblast growth factor (bFGF) (for review, see Halaban 1996). No single growth factor is sufficient for a full proliferative response (Matsumoto et al. 1991; Halaban et al. 1992). Interestingly, these factors have distinct effects on the differentiation program of melanocytes-HGF/SF stimulates, bFGF inhibits, whereas SLF is not required for differentiation (Dotto et al. 1989; Becker et al. 1992; Halaban et al. 1992; Murphy et al. 1992; MacKenzie et al. 1997). The proliferative and differentiation profiles of these growth factors suggest that the RTK pathways activated by them may execute unique functions, at least in part, during melanocyte development (Halaban et al. 1992). The study of how these pathways functionally interrelate in the context of melanoma represents an area of enormous experimental opportunity.

\section{RTKs and malignant melanoma}

In view of the dependence of melanocytes on complex RTK signaling for proper orchestration of basic cellular functions essential for development and homeostasis, it is not surprising that RTKs (and components of their signaling pathways) are frequent targets of the transformation process in melanocytes. For examples, the human epidermal growth factor receptor (EGFR) proto-oncogene, which maps to chromosome 7p12-13, is overexpressed (Koprowski et al. 1985; de Wit et al. 1992b; Ellis et al. 1992) in late stage melanomas harboring amplified copies of chromosome 7 (T rent 1991; Bastian et al. 1998). The FGF receptor (FGFR) also appears to play a role in melanoma. Contrary to normal melanocytes, which require supplementation of various growth factors in culture, virtually all melanoma cells can produce bFGF and grow autonomously through the creation of an bFGFFGFR autocrine loop ( $\mathrm{Hal}$ aban et al. 1988; Becker et al. 1989, 1992). Such a bFGF-FGFR autocrine loop has been shown to be essential for melanoma growth in vivo (Yayon et al. 1997; Wang and Becker 1997), again indicating involvement of RTK signaling in melanoma development.

There have been numerous reports, sometimes conflicting, describing the expression levels of genes encoding various growth factors and their RTKs in primary and metastatic melanomas as well as their derivative cell lines (see, e.g., Albino 1992; Shih and Herlyn 1994; Halaban 1996). When these studies are viewed collectively, a common theme appears to be the acquisition of autocrine signaling loops. These loops include members of the FGF family and their receptors; transforming growth factor $\alpha(T G F \alpha)$ and its receptor, the EGFR; and B61 and its receptor, epithelial cell kinase (ECK). Other RTKs showing strong expression include Erb-B2, IGF1R, and M et. Robust c-met, but not HGF/SF, expression has been observed in melanoma tissue and cells, and in some cases has been associated with progression to the metastatic state ( $\mathrm{N}$ atali et al. 1993; Saitoh et al. 1994; Rusciano et al. 1995; Hendrix et al. 1998). In human interconverted uveal melanoma cells, which are highly aggressive and preferentially disseminate to the liver, c-met expression has been correlated to high motogenic response and invasiveness (Hendrix et al . 1998). In contrast, Kit, a RTK which can inhibit melanoma growth, exhibits a loss or reduction in its expression in most melanomas (Funasaka et al. 1992; Lassam and Bickford 1992; Zakut et al. 1993; Gutman et al. 1994).

In addition to autocrine growth promoting effects, a number of RTK-activating growth factors characteristically produced by melanoma cells, such as the FGFs and PDGFs, can al so exert profound influences on the immediate microenvironment through paracrine signaling mechanisms (for review, see Rodeck and Herlyn 1991; Shih and Herlyn 1994). These include promotion of angiogenesis, extracellular matrix degradation and adhesive interactions, and suppression of immunologic response and antiproteolytic activity. These biological endpoints of RTK signaling have been proposed to account for the apparent association of RTK activation with metastatic progression in human and murine melanoma.

Perhaps the most convincing experimental evidence implicating RTK signaling pathways in the genesis and progression of melanoma comes from studies of animal models. One well-characterized model is a fish of the genus Xiphophorus, which develops melanoma in specific association with aberrant expression of the activated Xmrk gene; Xmrk encodes a novel transmembrane RTK related to the EGFR (Wittbrodt et al. 1989; Schartl and Adam 1992). In the mouse, ectopic transgene expression of an activated RTK encoded by the ret oncogene induced widespread skin hyperpigmentation and multifocal melanocytic tumors (Iwamoto et al. 1992). These transgenic mice did not demonstrate spontaneous metastasis of primary tumors, although established cul- 
tured cells from ret-induced tumors were metastatic when reintroduced into Balb/c nude mice as transplants (Taniguchi et al. 1992). The efficacy of activated ret in inducing melanoma was somewhat unexpected considering that c-ret expression is undetectable in normal melanocytes and melanoma cell lines ( $\mathrm{N}$ akamura et al. 1994; Easty et al. 1995). One possible interpretation of these data is that RTKs may play redundant roles by engaging and activating similar pathways integral to the development of melanoma.

More recently, a transgenic murine model was described in which mouse HGF/SF overexpression induced the stepwise development of cutaneous melanoma and, in $\sim 20 \%$ of tumor-bearing mice, ultimate progression to metastatic disease, a process that typically took more than a year (Takayama et al. 1996, 1997; Otsuka et al. 1998). Melanoma-genesis was driven in this model through constitutive activation of overexpressed endogenous M et by autocrine expression of the HGF/SF transgene. The rel atively long latency indicates that HGF/SF overexpression is necessary, but not sufficient, for the development of malignant melanoma. This model therefore encourages an anal ysis of candi date genes associated with acquisition of the metastatic phenotype, such as p16 IN K4a,$p 19^{\mathrm{ARF}}$, and other RTKs, and the application of various techniques capable of identifying genes that are differentially expressed during late stages of melanoma progression.

Progression to the invasive-metastatic state mandates the acquisition of a variety of essential attributes, including the ability to degrade local extracellular matrix, produce appropriate cell adhesion molecules, migrate into adjacent tissue and vessels, colonize a distant site, and stimulate angiogenesis. Ectopical ly expressed HGF/ SF may facilitate metastasis because it can inherently engage pathways playing an essential role in all these processes (for review, see Matsumoto and $\mathrm{N}$ akamura 1996). M ost significantly, HGF/SF can potently dissociate, or 'scatter' sheets of epithelia into individual mesenchymal-type cells in vitro, and regulate, through cM et, epithelial / mesenchymal conversion and migration of skeletal muscle precursor cells from the somitic dermomyotome (Bladt et al. 1995). The same type of conversion process occurs during the formation of melanoblasts in the neural crest. It has long been appreciated that crest-derived cells, and melanoblasts in particular, are unusually invasive cell types (Erickson et al. 1980). Perhaps constitutive activation of $M$ et in mature melanocytes predisposes to future metastatic capability by encouraging conversion to a more mesenchymal and invasive cell type, providing a potential explanation for the notoriously aggressive and deadly nature of melanomas. This is a testable hypothesis that can now be addressed in transgenic mouse models expressing wild-type or mutant derivatives of c-met in melanocytes.

\section{Molecular pathways goveming metastasis: lessons from Met and Ras}

The genetic dissection of pathways playing an essential role in the metastatic behavior of melanoma represents an important focus of the field. The distinct clinical outcomes of transgenic mice expressing activated Ras or HGF/SF in melanocytes has been particularly informative. As mentioned above, the melanocyte-specific expression of activated $\mathrm{H}$-Ras on an IN K4a/ARF-deficient background led to the development of spontaneous cutaneous melanoma with high penetrance and short latency. These tumors were highly invasive but did not progress to a metastatic phenotype. In contrast, transgenic mice overexpressing HGF/SF developed malignant melanoma with a relatively high incidence of metastasis, al beit with a longer latency. How can we account for these phenotypic differences?

In this regard, what is known about RTK downstream signaling pathways in general, and M et pathways in particular, is enlightening. Typically, growth factor binding induces RTK dimerization and activation of the cytoplasmic tyrosine kinase domain, resulting in RTK autophosphorylation at multiple intracellular tyrosine residues, and subsequent phosphorylation/activation of specific substrates (Weiss and Schlessinger 1998). The main function of the autophosphorylated tyrosines is to bind to and activate specific receptor targets containing Srchomology-2 (SH2) domains. These include a variety of catalytic transducers, noncatalytic signal amplifiers, and molecular adaptor proteins (Schlessinger and Ullrich 1992; Pawson 1995). For the generic RTK, each autophosphorylation site is utilized by a specific $\mathrm{SH} 2$ protein, and therefore for a particular pathway and cellular response. Unlike other RTKs, M et has two closely spaced autophosphorylation sites, Y 1349 and Y 1356, embedded within tandemly repeated degenerate sequences. Both sites are requi red for signal transduction, and each is able to bind multiple $\mathrm{SH} 2$-containing proteins, including signal transducers such as PI3-K, phospholipase C- $\gamma$ (PLC$\gamma$ ), Stat3, Src, and Grb2, as well as the Grb2-associated docking protein, Gabl (Ponzetto et al. 1994, 1996; Weidner et al. 1995, 1996).

Studies using specific inhibitors and Met mutants have begun to assign specific factor binding sites on $M$ et and their corresponding downstream pathways to the various HGF/SF-induced biological activities (Fig. 5). For example, Grb2 and subsequent Ras/MAPK and/or JNK activation are mandatory for maximum proliferative re sponse and complete transformation (Ponzetto et al. 1996; Rodrigues et al. 1997); PI3-K activation is clearly required for HGF/SF-induced scattering (Royal and Park 1995; Derman et al. 1995; Khwaja et al. 1998), and has been reported to be a transducer of tumor invasiveness (Kotel evets et al. 1998); PLC- $\gamma$ has been implicated in cell chemotaxis (Derman et al. 1996); association with Src correl ates with a highly metastatic state ( $\mathrm{M}$ ao et al. 1997); and full induction of the urokinase proteolysis network (Jeffers et al. 1996) involves both Ras and PI3-K (Besser et al. 1997). On the other hand, the complex process of branching morphogenesis is dependent on a ST AT pathway, PI3-K, and Grb2-dependent Gab1 binding (Derman et al. 1996; Fournier et al. 1996; Weidner et al. 1996; N guyen et al. 1997; Boccaccio et al. 1998). 


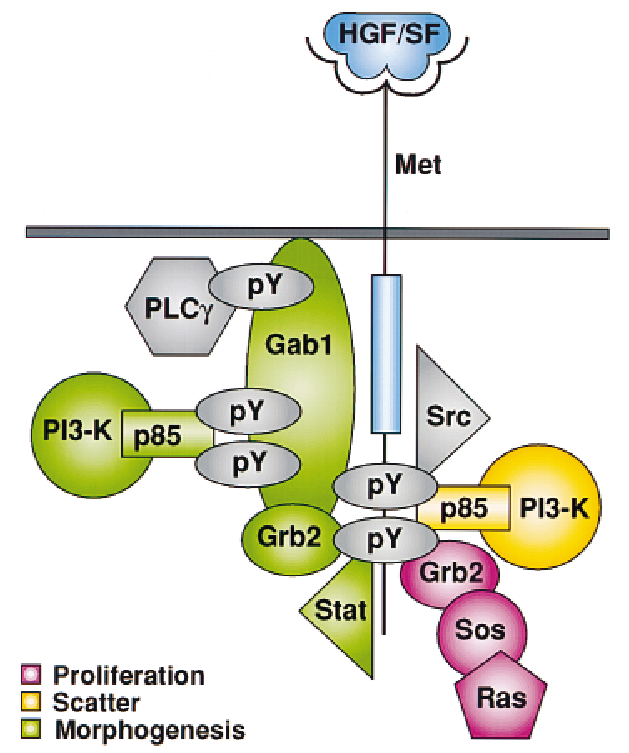

Figure 5. Schematic representation of the correlation between HGF/SF-induced, Met-associated biological activities and their corresponding signal transduction pathways. Colored components are those that have been shown experimentally to be required, but not necessarily sufficient, for a full biological response. This figure, based largely on genetic data, has been simplified for the purposes of discussion; in reality, complex biological activities undoubtedly occur through coordination and integration of multiple pathways. A full proliferative response in M et-expressing cells requires functional Ras, which is activated through Grb2/SOS (purple) or Shc (not shown). PI3-K has clearly been implicated in cell scattering; analysis of $M$ et mutants with impaired Grb2 binding showed that the PI3-K that binds most directly to $M$ et (yellow) is sufficient for implementing the HGF/SF-induced scatter phenotype. The relative contribution of the Gabl-associated PI3-K in scattering is not known, but is not needed. Branching morphogenesis has been shown to require Grb2/Gabl binding, as well as activation of Stat and PI3-K pathways (green). This schematic presumes the involvement of the Gabl-related PI3-K, but the relative contribution of the two PI3-K binding sites in morphogenesis is largely unknown. See text for details and references.

Even a cursory examination of the complexities of the Met signaling newtork (Fig. 5) reveals that Ras activation represents but a subset of downstream effector pathways of Met. Although Grb2-mediated Ras activation is absolutely required for c-met-associated transformation (Fixman et al. 1996; Ponzetto et al. 1996; Bardelli et al . 1997), the former has been shown to be insufficient for metastasis. Giordano et al. (1997) have recently demonstrated that a c-met mutation that superactivates the Grb2-mediated Ras/M APK pathway but prevents binding of other signal transducers confers enhanced transforming capability, but extinguishes metastatic potential. Interestingly, an invasive phenotype was rescued by coexpressing a complementary mutant $M$ et that could recruit all factors not requiring Grb2, including PI3-K (Giordano et al. 1997). Furthermore, expression of constitutively active PI3-K fully rescued the ability of cells to metastasize, indicating that simultaneous activation of Ras and
PI3-K pathways is required to unleash the metastatic potential of $M$ et (C. Ponzetto, pers. comm.). The fact that Ras/MAPK activation is not sufficient to induce the metastatic phenotype provides a plausible rationale for the behavioral differences observed between the metastatic HGF/SF and the nonmetastatic $\mathrm{H}$-Ras transgenic melanomas.

\section{The genomic frontier of melanoma}

The INK4a/ARF locus is clearly the most prominent melanoma susceptibility locus in humans, however numerous studies indicate that it is not the only one. The existence of other disease loci has been made evident from melanoma kindred that do not exhibit linkage to 9p21 and from cytogenetic data uncovering recurrent genomic alterations. Specifically, alterations on human chromosomes 1, 6, and 10 appear to be common events (for review, see Welch and Goldberg 1997). Although a convincing disease gene candidate has yet to be identified for these loci, a region on the long arm of chromosome 10 (10q24-26) have captured substantial attention due to its involvement is a wide spectrum of human cancers. Loss of heterozygosity and chromosomal rearrangements spanning 10q24-26 have been observed in melanoma (Parmiter et al. 1988; Robertson et al. 1998), malignant gl iomas (Albarosa et al. 1995; Chiariello et al. 1998), Iymphomas (Speaks et al. 1992), and prostate adenocarcinomas (see bel ow), providing strong evidence for the presence of one or more tumor suppressors within this locus. Specifical ly, the M yc antagonist M xi 1 and the phosphatase PTEN/MMACl have emerged as prime candidates based upon the fact that germline del etion of either gene leads to development of a cancer-prone condition in the mouse (Di Cristofano et al. 1998; SchreiberAgus et al. 1998). Furthermore, intragenic mutations have been observed in human prostate cancers (Eagle et al. 1995; Cairns et al. 1997; Prochownik et al. 1998). To clarify the roles of Mxil and PTEN/MMAC1 in melanoma pathogenesis, current efforts are focused on comprehensive mutational analyses of Mxil and PTEN / MMAC 1 in primary human melanoma samples as well as genetic cooperation studies in the mouse. Along these lines, a newly developed and el egant in vitro loss of heterozygosity-chromosome transfer assay has pointed to 10 q23 as the chromosome 10 locus bearing a potent growth suppressor of melanoma cells (Robertson et al. 1998). PTEN / M M A C 1 appears to be at least one of the genes in this region targeted for loss and its re-introduction into PTEN-deficient melanoma cells suppresses growth (Robertson et al. 1998). Interestingly, 60\%-70\% of sporadic melanomas express wild-type PTEN/ M M AC 1 (Guldberg et al. 1997; T sao et al. 1998), and the reintroduction of PTEN/MMACl into such melanoma cells appears to have no growth suppressive effect (Robertson et al. 1998). Such findings are consistent with the existence of additional melanoma suppressor genes residing on chromosome 10.

Evidence for a melanoma locus at chromosome 1p36 has accumulated from the linkage analysis of individuals 
with early onset of disease, predisposition toward multi ple primary mel anoma, and/ or the presence of multi ple dysplastic nevi. An autosomal dominant mode of inheritance for the 1p36-linked lesion for melanoma and DNS has been proposed although some questions still surround the relevance of this locus to melanoma susceptibility (for review, see Greene 1997; Wel ch and Goldberg 1997). For chromosome 6, cytogenetic rearrangements spanning 6q22-27 have been observed in both early- and late-stage primary tumors (Welch et al. 1994; M iele et al. 1996; for review, see Welch and Goldberg 1997). The findings that the EGFR locus is amplified and that overexpression of EGFR appears to correlate with tumor aggressiveness, have pointed to EGFR as a potential candidate RTK that is directly involved in the human melanomagenesis (see Table 2). Moreover, the ability of $M$ et activation to promote melanoma in an experimental mouse model (described above), although not yet confirmed in the human disease, reinforces the view that activation of pathways extending from RTKs in general may contribute to the pathogenesis of melanoma.

Ongoing and foreseeable efforts promise to yi el $d$ a rich harvest of genes crucial to the development of malignant melanoma and, with such genes in hand, emphasis will shift towards how their dysregulation contributes to the melanoma process. Genetic verification of a causal role for these genes/loci will remain an important exercise particularly because many of the genetic lesions identified to date, with few exceptions, have come from the cytogenetic anal ysis of far-advanced tumors, particularly metastatic disease. This fact, coupled with the inherent genomi c instability of malignant mel anoma, emphasizes the need for molecular studies to utilize primary, early stage di sease samples. In addition, a key challenge to the melanoma gene hunter is the need to appreciate that mel anoma actual ly represents a diverse coll ection of diseases, often grouped into one molecular heap. Thus, a better genetic roadmap of tumor progression from melanocyte to metastatic mel anoma will emerge with careful attentiveness to tumor stage and histologic subtype. On another level, the melanoma field has a strong need for tractable genetic systems to aid in the discovery, verification, and functional analysis of the growing collection of melanoma susceptibility genes. Mouse models are likely to provide such systems as available data suggest that mouse and human melanoma are si milar in etiology (Chin et al. 1997). If this proves true, then the meticulous construction of mouse models harboring genetic lesions encountered in human melanoma should provide at least one complementary approach to the genomic efforts in human melanoma. Beyond their obvious impact on the basic understanding of molecular pathogenesis and gene discovery, these melanoma mouse models would find great use in both chemopreventive and chemotherapeutic efforts directed towards irradication of this modern black plague.

\section{Acknowledgments}

We thank Drs. Mark Jacobson, Meenhard Herlyn, Nicole
Schrei ber-Agus, Tal Raveh, Carola Ponzetto, and M orag Park for critical reading of the manuscript, and members of the DePinho lab for hel pful comments. We are al so grateful to Dr. Ponzetto for communicating data prior to publication. L.C. is supported by a grant from the National Institutes of Health $(\mathrm{NIH})$ (K08AR02104-01). Work in the DePinho lab is supported by grants from the NIH (R01HD28317, R01EY09300, and R01EY 11267) and from the American Heart Association. R.A.D. is an American Cancer Society Research Professor and a recipient of the Irma T. Hirschl A ward.

\section{References}

Albarosa, R., S. DiDonato, and G. Finocchiaro. 1995. Redefinition of the coding sequence of the MXII gene and identification of a polymorphic repeat in the $3^{\prime}$-non-coding region that allows the detection of loss of heterozygosity of chromosome 10q25 in glioblastomas. Hum. Genet. 95: 709-711.

Albino, A.P. 1992. The role of oncogenes and growth factors in progressive melanoma-genesis. Pigment Cell Res. (Suppl.) 2: 199-218.

- - - 1995. Genes involved in melanoma susceptibility and progression. Curr. Opin. Oncol. 7: 162-169.

Albino, A.P., R. Le Strange, A.I. Oliff, M .E. Furth, and L.J. Old. 1984. Transforming ras genes from human melanoma: $A$ manifestation of tumour heterogeneity? Nature 308: 69-72.

Albino, A.P., D.M. N anus, I.R. Mentle, C. Cordon-Cardo, N.S. McN utt, J. Bressler, and M. Andreeff. 1989. Analysis of ras oncogenes in malignant melanoma and precursor lesions: Correlation of point mutations with differentiation phenotype. Oncogene 4: 1363-1374.

Albino, A.P., G. Sozzi, D.M. Nanus, S.C. Jhanwar, and A.N. Houghton. 1992. Malignant transformation of human melanocytes: Induction of a complete melanoma phenotype and genotype. Oncogene 7: 2315-2321.

Ball, N.J., J.J. Yohn, J.G. Morelli, D.A. Norris, L.E. Golitz, and J.P. Hoeffler. 1994. Ras mutations in human melanoma: A marker of malignant progression. J. Invest. Dermatol. 102: 285-290.

Bardelli, A., P. Longati, D. Gramaglia, M.C. Stella, and P.M. Comoglio. 1997. Gabl coupling to the HGF/M et receptor multifunctional docking site requires binding of Grb2 and correlates with the transforming potential. Oncogene 15: 3103-3111.

Barnhill, R.L., M.C. Mihm, Jr., T.B. Fitzpatrick, and A.J. Sober. 1993. N eoplasms: Malignant melanoma. In Dermatology in general medicine (ed. T.B. Fitzpatrick, A.Z. Eisen, K. Wolff, I.M. Freedberg, and K.F. Austen), pp. 1078-1115. McGrawHill, New York, NY.

Bastian, B.C., P.E. LeBoit, H. Hamm, E.B. Brocker, and D. Pinkel. 1998. Chromosomal gains and losses in primary cutaneous melanomas detected by comparative genomic hybridization. Cancer Res. 58: 2170-2175.

Becker, D., C.B. Meier, and M. Herlyn. 1989. Proliferation of human malignant melanomas is inhibited by antisense oligodeoxynucleotides targeted against basic fibroblast growth factor. EMBO J. 8: 3685-3691.

Becker, D., P.L. Lee, U. Rodeck, and M. Herlyn. 1992. Inhibition of the fibroblast growth factor receptor 1 (FGFR-1) gene in human melanocytes and malignant melanomas leads to inhibition of proliferation and signs indicative of differentiation. Oncogene 7: 2303-2313.

Bennett, D.C. 1993. Genetics, development, and malignancy of melanocytes. Int. Rev. Cytol. 146: 191-260.

Bennett, J.P. and P. Hall. 1994. M oles and melanoma: A history. 
Ann. R. Coll. Surg. Engl. 76: 373-380.

Besser, D., A. Bardelli, S. Didichenko, M. Thelen, P.M. Comoglio, C. Ponzetto, and Y. N agamine. 1997. Regulation of the urokinase-type plasminogen activator gene by the oncogene Tpr-M et involves GRB2. Oncogene 14: 705-711.

Bladt, F., D. Riethmacher, S. Isenmann, A. A guzzi, and C. Birchmeier. 1995. Essential role for the c-met receptor in the migration of myogenic precursor cells into the limb bud. Nature 376: 768-771.

Boccaccio, C., M. Ando, L. Tamagnone, A. Bardelli, P. Michieli, C. Battistini, and P.M. Comoglio. 1998. Induction of epithelial tubules by growth factor HGF depends on the STAT pathway. Nature 391: 285-288.

Bottaro, D.P., J.S. Rubin, D.L. Fal etto, A.M . Chan, T.E. Kmiecik, G.F. Vande Woude, and S.A. Aaronson. 1991. Identification of the hepatocyte growth factor receptor as the c-met protooncogene product. Science 251: 802-804.

Brenner, A., A. Pal adugu, H. Wang, O.I. Olopade, M .F. Dreyling, and C.M. Aldaz. 1996. Preferential loss of expression of p16IN K4a rather than p19ARF in breast cancer. Clin. Cancer Res. 2: 1993-1998.

Brotherton, D.H., V. Dhanaraj, S. Wick, L. Brizuela, P.J. Domaille, E. Volyanik, X. Xu, E. Parisini, B.O. Smith, S.J. Archer, M. Serrano, S.L. Brenner, T.L. Blundell, and E.D. Laue. 1998. Crystal structure of the complex of the cyclin D-dependent kinase Cdk6 bound to the cell-cycle inhibitor p19 1N K4d. Nature 395: 244-250.

Cairns, P., K. Okami, S. Halachmi, N. Halachmi, M. Esteller, J.G. Herman, J. Jen, W.B. Isaacs, G.S. Bova, and D. Sidransky. 1997. Frequent inactivation of PTEN / M MAC1 in primary prostate cancer. Cancer Res. 57: 4997-5000.

Chabot, B., D.A. Stephenson, V.M. Chapman, P. Besmer, and A. Bernstein. 1988. The proto-oncogene c-kit encoding a transmembrane tyrosine kinase receptor maps to the mouse $\mathrm{W}$ locus. Nature 335: 88-89.

Chiariello, E., L. Roz, R. Albarosa, I. Magnani, and G. Finocchiaro. 1998. PTEN / M MAC1 mutations in primary glioblastomas and short-term cultures of malignant gliomas. Oncogene 16: 541-545.

Chin, L., J. Pomerantz, D. Polsky, M. Jacobson, C. Cohen, C. Cordon-Cardo, J.W. Horner, and R.A. DePinho. 1997. Cooperative effects of INK4a and ras in melanoma susceptibility in vivo. Genes \& Dev. 11: 2822-2834.

Chin, L., J. Pomerantz, and R.A. DePinho. 1998. The IN K4a/ ARF tumor suppressor: One-two products-two pathways. Trends Biochem. Sci. 23: 291-296.

Cordon-Cardo, C. 1995. Mutations of cell cycle regulators. Biological and clinical implications for human neoplasia. Am. J. Pathol. 147: 545-560.

de Wit, P.E., A.H. Hopman, G.N . van Muijen, D.F. Smeets, J.L. Beck, O. M oesker, and D.J. Ruiter. 1992a. In situ detection of supernumerary aberrations of chromosome-specific repetitive DNA targets in interphase nuclei in human melanoma cell lines and tissue sections. J. Invest. Dermatol. 98: 450458.

de Wit, P.E., S. Moretti, P.G. Koenders, M.A. Weterman, G.N . van Muijen, B. Gianotti, and D.J. Ruiter. 1992b. Increasing epidermal growth factor receptor expression in human meIanocytic tumor progression. J. Invest. Dermatol. 99: 168173.

Derman, M.P., M.J. Cunha, E.J. Barros, S.K. Nigam, and L.G. Cantley. 1995. HGF-mediated chemotaxis and tubulogenesis require activation of the phosphatidylinositol 3-kinase. Am. J. Physiol. 268: F1211-1217.

Derman, M.P., J.Y. Chen, K.C. Spokes, Z. Songyang, and L.G. Cantley. 1996. An 11-amino acid sequence from c-met ini- tiates epithelial chemotaxis via phosphatidylinositol 3-kinase and phospholipase C. J. Biol. Chem. 271: 4251-4255.

Di Cristofano, A., B. Pesce, C. Cordon-Cardo, and P.P. Pandolfi. 1998. Pten is essential for embryonic development and tumour suppression. Nature Genet. 19: 348-355.

Dotto, G.P., G. M oellmann, S. Ghosh, M. Edwards, and R. Halaban. 1989. Transformation of murine melanocytes by basic fibroblast growth factor CDN A and oncogenes and selective suppression of the transformed phenotype in a reconstituted cutaneous environment. J. Cell Biol. 109: 3115-3128.

Dracopoli, M.C., P. Harnett, S.J. Bale, B.Z. Stanger, M.A. Tucker, D.E. Housman, and R.F. Kefford. 1998. Loss of allel es from the distal short arm of chromosome 1 occurs late in melanoma tumor progression. Proc. Natl. Acad. Sci. 86: 4614-4618.

Eagle, L.R., X. Yin, A.R. Brothman, B.J. Williams, N.B. Atkin, and E.V. Prochownik. 1995. Mutation of the MXII gene in prostate cancer. Nature Genet. 9: 249-255.

Easty, D.J., M. Herlyn, and D.C. Bennett. 1995. Abnormal protein tyrosine kinase gene expression during melanoma progression and metastasis. Int. J. Cancer 60: 129-136.

Elder, D.E. 1987. Metastatic melanoma. In Pigment cell (ed. D.E. Elder), pp. 182. Karger, Basel, Switzerland.

Ellis, D.L., L.E. King, and L.B. N anney. 1992. Increased epidermal growth factor receptors in melanocytic lesions. J. Am. Acad. Dermatol. 27: 539-546.

Erickson, C.A., K.W. Tosney, and J.A. Weston. 1980. A nalysis of migratory behavior of neural crest and fibroblastic cells in embryonic tissues. Dev. Biol. 77: 142-156.

FitzGerald, M.G., D.P. Harkin, S. Silva-Arrieta, D.J. MacDonald, L.C. Lucchina, H. Unsal, E. O'N eill, J. Koh, D.M. Finkelstein, K.J. Issel bacher, A.J. Sober, and D.A. Haber. 1996. Prevalence of germ-line mutations in p16, p19ARF, and CDK4 in familial melanoma: Analysis of a clinic-based population. Proc. Natl. Acad. Sci. 93: 8541-8545.

Fixman, E.D., T.M. Fournier, D.M. Kamikura, M.A. Naujokas, and M. Park. 1996. Pathways downstream of Shc and Grb2 are required for cell transformation by the tpr-M et oncoprotein. J. Biol. Chem. 271: 13116-13122.

Fleischman, R.A., D.L. Saltman, V. Stastny, and S. Zneimer. 1991. Deletion of the c-kit protooncogene in the human developmental defect piebald trait. Proc. Natl. Acad. Sci. 88: 10885-10889.

Flores, J.F., G.J. Walker, J.M. Glendening, F.G. Haluska, J.S. Castresana, M.P. Rubio, G.C. Pastorfide, L.A. Boyer, W.H. Kao, M.L. Bulyk, R.L. Barnhill, N.K. Hayward, D.E. Housman, and J.W. Fountain. 1996. Loss of the p16INK4a and p15INK4b genes, as well as neighboring 9p21 markers, in sporadic melanoma. Cancer Res. 56: 5023-5032.

Flores, J.F., P.M. Pollack, G.J. Walker, J.M. Glendening, A.H. Lin, J.M. Palmer, M.K. Walters, N.K. Hayward, and J.W. Fountain. 1997. Analysis of the DCKN2A, CDKN2B, and CDK4 genes in 48 Australian melanoma kindreds. Oncogene 15: 2999-3005.

Fournier, T.M., D. Kamikura, K. Teng, and M. Park. 1996. Branching tubulogenesis but not scatter of madin-darby canine kidney cells requires a functional Grb2 binding site in the $M$ et receptor tyrosine kinase. J. Biol. Chem. 271: 2221122217.

Funasaka, Y., T. Boulton, M. Cobb, Y. Yarden, B. Fan, S.D. Lyman, D.E. Williams, D.M. Anderson, R. Zakut, and Y. Mishima. 1992. c-Kit-kinase induces a cascade of protein tyrosine phosphorylation in normal human melanocytes in response to mast cell growth factor and stimulates mitogenactivated protein kinase but is down-regulated in melanomas. Mol. Biol. Cell 3: 197-209. 
Funk, J.O., P.I. Schiller, M.T. Barrett, D.J. Wong, P. Kind, and C.A. Sander. 1998. p16INK4a expression is frequently decreased and associated with 9p21 loss of heterozygosity I sporadic melanoma. J. Cutan. Pathol. 25: 291-296.

Gardie, B., J. Cayuela, S. Martini, and F. Sigaux. 1998. Genomic alterations of the p19ARF encoding exons in T-cell acute Iymphoblastic leukemia. Blood 91: 1016-1020.

Gause, P.R., M. Lluria-Prevatt, W.N. Keith, A. Balmain, S. Linardopolous, J. Warneke, and M.B. Powell. 1997. Chromosomal and genetic alterations of 7,12-dimethylbenz[a]anthracene-induced melanoma from TP-ras transgenic mice. Mol. Carcin. 20: 78-87.

Geissler, E.N ., M.A. Ryan, and D.E. Housman. 1988. The dominant-white spotting (W) locus of the mouse encodes the c-kit proto-oncogene. Cell 55: 185-192.

Giebel, L.B. and R.A. Spritz. 1991. Mutation of the KIT (mast/ stem cell growth factor receptor) protooncogene in human piebal dism. Proc. Natl. Acad. Sci. 88: 8696-8699.

Giordano, S., A. Bardelli, Z. Zhen, S. Menard, C. Ponzetto, and P.M. Comoglio. 1997. A point mutation in the MET oncogene abrogates metastasis without affecting transformation. Proc. Natl. Acad. Sci. 94: 13868-13872.

Gonzalez-Zulueta, M., C.M. Bender, A.S. Yang, T. N guyen, R.W. Beart, J.A. Van Tomout, and P. Jones. 1995. Methylation of the 5' CpG island of the p16/CDKN2 tumor suppressor gene in normal and transformed human tissues correlates with gene silencing. Cancer Res. 55: 4531-4535.

Gonzal go, M.L., C.M. Bender, E.H. You, J.M. Glendening, J.F. Flores, G.J. Walker, N.K. Hayward, P.A. Jones, and J.W. Fountain. 1997. Low frequency of p16/CDKN2A methylation in sporadic melanoma: Comparative approaches for methylation analysis of primary tumors. Cancer Res. 57: 5336-5347.

Greene, M.H. 1997. Genetics of cutaneous melanoma and nevi. Mayo Clin. Proc. 72: 467-474.

Greene, M.H., W.H. Clark, M.A. Tucker, K.H. Kraemer, D.E. Elder, and M.C. Fraser. 1985. High risk of malignant melanoma in melanoma-prone families with dysplastic nevi. Ann. Intern. Med. 102: 458-465.

Grover, R., J.S. Chana, G.D. Wilson, P.I. Richman, and R. Sanders. 1998. An analysis of p16 protein expression in sporadic malignant melanoma. Melanoma Res. 8: 267-272.

Gruis, N.A., J. Weaver-Feldhaus, Q. Liu, C. Frye, R. Eeles, I. Orlow, L. Lacombe, V. Ponce-Castaneda, P. Lianes, E. Latres et al. 1995. Genetic evidence in melanoma and bladder cancers that p16 and p53 function in separate pathways of tumor suppression. Am. J. Pathol. 146: 1199-1206.

Guldberg, P., P. thor Straten, A. Birck, V. A hrenkiel, A.F. Kirkin, and J. Zeuthen. 1997. Disruption of the MMAC1/PTEN gene by deletion or mutation is a frequent event in malignant melanoma. Cancer Res. 57: 3660-3663.

Gutman, M., R.K. Singh, R. Radinsky, and M. Bar-Eli. 1994. Intertumoral heterogeneity of receptor-tyrosine kinases expression in human melanoma cell lines with different metastatic capabilities. Anticancer Res. 14: 1759-1765.

Halaban, R. 1996. Growth factors and melanomas. Sem. O ncol. 23: 673-681.

Halaban, R., B.S. Kwon, S. Ghosh, P. Delli Bovi, and A. Baird. 1988. bFGF as an autocrine growth factor for human melanomas. Oncogene Res. 3: 177-186.

Halaban, R., J.S. Rubin, Y. Funasaka, M. Cobb, T. Boulton, D. Faletto, E. Rosen, A. Chan, K. Yoko, and W. White. 1992. Met and hepatocyte growth factor/scatter factor signal transduction in normal melanocytes and melanoma cells. Oncogene 7: 2195-2206.
Hal uska, F.G. and F.S. Hodi. 1998. M olecular genetics of familial cutaneous melanoma. J. Clin. Oncol. 16: 670-682.

Hangaishi, A., S. Ogawa, N. Imamura, S. M iyawaki, Y. Miura, N. Uike, C. Shimazaki, N. Emi, K. Takeyama, S. Hirosawa et al. 1996. Inactivation of multiple tumor-suppressor genes involved in negative regulation of the cell cycle, MTS1/ p16INK4a/CDKN2, NRS2/p15INK4B, p53, and rb genes in primary lymphoid malignancies. Blood 87: 4949-4958.

Harper, J.W. and S.J. Elledge. 1996. Cdk inhibitors in development and cancer. Curr. O pin. Genet. Dev. 6: 56-64.

Hecht, F. 1989. The annals of cancer genetics: The description by $\mathrm{N}$ orris of hereditary malignant melanoma of the skin in 1820. Cancer Genet. Cytogenet. 42: 153-156.

Heinzel, P.A., P. Balaram, and H.U. Bernard. 1996. Mutations and polymorphisms in the p52, p21, and p16 genes in oral carcinomas of Indian betel quid chewers. Int. J. Cancer 68: 420-423.

Hendrix, M.J., E.A. Seftor, R.E. Seftor, D.A. Kirschmann, L.M. Gardner, H.C. Boldt, M. M eyer, J. Pe'er, and R. Fol berg. 1998. Regulation of uveal melanoma interconverted phenotype by hepatocyte growth factor/scatter factor (HGF/SF). Am. J. Pathol. 152: 855-863.

Herlyn, M. 1993. M olecular and cellular biology for melanoma. pp. 1-102. R.G. Landes Co., Austin, TX.

Hussussian, C.J., J.P. Struewing, A.M. Goldstein, P.A. Higgins, D.S. Ally, M.D. Sheahan, W.H. Clark, Jr., M.A. Tucker, and N.C. Dracopoli. 1994. Germline p16 mutations in familial melanoma. Nature Genet. 8: 15-21.

Iwamoto, T., M. Takahashi, M. Ohbayashi, and I. Nakashima. 1992. The ret oncogene can induce melanogenesis and melanocyte development in Wv/Wv mice. Exp. Cell Res. 200: 410-415.

Jafari, M., T. Papp, S. Kirchner, U. Diener, D. Henschler, G. Burg, and D. Schiffmann. 1995. Analysis of ras mutations in human melanocytic lesions: Activation of the ras gene seems to be associated with the nodular type of human malignant melanoma. J. Cancer Res. Clin. O ncol. 121: 23-30.

Jeffers, M., S. Rong, and G.F. Vande Woude. 1996. Enhanced tumorigenicity and invasion-metastasis by hepatocyte growth factor/scatter factor-met signalling in human cells concomitant with induction of the urokinase proteolysis network. Mol. Cell Biol. 16: 1115-1125.

Kamb, A. 1995. Cell-cycle regulators and cancer. Trends Genet. 11: 136-140.

Kamb, A., D. Shattuck-Eidens, R. Eeles, Q. Liu, N.A. Gruis, W. Ding, C. Hussey, T. Tran, Y. Miki, J. Weaver-Feldhaus et al. 1994. A nalysis of the p16 gene (CDKN2) as a candidate for the chromosome $9 p$ melanoma susceptibility locus. Nature Genet. 8: 23-26.

Kamijo, T., F. Zindy, M.F. Roussel, D.E. Quelle, J.R. Downing, R.A. Ashmun, G. Grosveld, and C.J. Sherr. 1997. Tumor suppression at the mouse INK4a locus mediated by the al ternative reading frame product p19ARF. Cell 91: 649-659.

Kamijo, T., J.D. Weber, G. Zambetti, F. Zindy, M.F. Roussel, and C.J. Sherr. 1998. Functional and physical interactions of the ARF tumor suppressor with p53 and M dm2. Proc. Natl. Acad. Sci. 95: 8292-8297.

Khwaja, A., K. Lehmann, B.M. Marte, and J. Downward. 1998. Phosphoinositide 3-kinase induces scattering and tubulogenesis in epithelial cells through a novel pathway. J. Biol. Chem. 273: 18793-18801.

Kinoshita, I., H. Dosaka-Akita, T. Michina, K. Akie, M. Nishi, H. Hiroumi, F. Hommura, and Y. Kawakami. 1996. Altered p16IN K4a and retinoblastoma protein status in non-smallcell lung cancer; potential synergistic effect with altered p53 
protein on proliferative activity. Cancer Res. 56: 5557-5562.

Kinzler, K.W. and B. Vogelstein. 1996. Lessons from hereditary colorectal cancer. Cell 87: 159-170.

Koprowski, H., M. Herlyn, G. Balaban, A. Parmiter, A. Ross, and P. N owell. 1985. Expression of the receptor for epidermal growth factor correlates with increased dosage of chromosome 7 in malignant melanoma. Somat. Cell Mol. Genet. 11: 297-302.

Kas, L., A. Aronzon, H. Takayam, F. Maina, C. Ponzatto, G. Merlino, and W. Pavan. 1998. HGF/SF-M et signaling in neural crest-derived melanocyte development. Pig Cell Res. (in press).

Kotelevets, L., V. N oe, E. Bruyneel, E. Myssiakine, E. Chastre, M. Mareel, and C. Gespach. 1998. Inhibition by plateletactivating factor of Src- and hepatocyte growth factor-dependent invasiveness of intestinal and kidney epithelial cells. Phosphatidylinositol 3 '-kinase is a critical mediator of tumor invasion. J. Biol. Chem. 273: 14138-14145.

Kumar, R., B. Lundh Rozell, J. Louhelainen, and K. Hemminki. 1998. Mutations in the CDKN2A (p16I NK4a) gene in microdissected sporadic primary melanomas. Int. J. Cancer 75: 193-198.

Kunisada, T., H. Yoshida, H. Yamazaki, A. Miyamoto, H. Hemmi, E. Nishimura, L.D. Shultz, S.I. Nishikawa, and S.I. Hayashi. 1998. Transgene expression of steel factor in the basal layer of epidermis promotes survival, proliferation, differentiation and migration of melanocyte precursors. Development 125: 2915-2923.

Laennéc, R.T.H. 1812. Extrait au memoire de M Laennec, sur les melanoses. Bull. Ec. Soc. Med. 24.

Lassam, N. and S. Bickford. 1992. Loss of c-kit expression in cultured melanoma cells. Oncogene 7: 51-56.

Le Douarin, N. 1982. The neural crest. p. 1-259. Cambridge University Press, Cambridge, UK.

Liu, L., N.J. Lassam, J.M. Slingerland, D. Bailey, D. Cole, R. Jenkins, and D. Hogg. 1995. Germline p16INK4A mutation and protein dysfunction in a family with inherited melanoma. Oncogene 11: 405-412.

MacKenzie, M.A.F., S.A. Jordan, P.S. Budd, and I.J. Jackson. 1997. Activation of the receptor tyrosine kinase Kit is required for the proliferation of melanoblasts in the mouse embryo. Dev. Biol. 192: 99-107.

MacKie, K.M., N. Andrew, W.G. Lanyon, J.M. Connor. 1998. CDKN2A germline mutations in U.K. patients with familial melanoma and multiple primary melanomas. J. Invest. Dermatol. 111: 260-272.

Mael andsmo, G.M., V.A. Florenes, E. Hovig, T. Oyjord, O. Engebraaten, R. Holm, A.-L. Borresen, and O. Fodstad. 1996. Involvement of the $\mathrm{pRb} / \mathrm{p} 16 / \mathrm{cdk} 4 / \mathrm{cyclin} \mathrm{D} 1$ pathway in the tumorigenesis of sporadic malignant melanomas. Br. J Cancer 73: 909-916.

Mao, W., R. Irby, D. Coppola, L. Fu, M. Wloch, J. Turner, H. Yu, R. Garcia, R. Jove, and T.J. Yeatman. 1997. Activation of c-Src by receptor tyrosine kinases in human colon cancer cells with high metastatic potential. Oncogene 15: 3083-3090.

Matsumoto, K. and T. N akamura. 1996. Emerging multipotent aspects of hepatocyte growth factor. J. Biochem. (Tokyo) 119: $591-600$.

M atsumoto, K., H. Tajima, and T. N akamura. 1991. Hepatocyte growth factor is a potent stimulator of human melanocyte DNA synthesis and growth. Biochem. Biophys. Res. Commun. 176: 45-51.

Matsumura, Y., C. Nishigori, T. Yagi, S. Imamura, and H. Tkebe. 1998. Mutations of p16 and p15 tumor suppressor genes and replication errors contribute independently to the pathogenesis of sporadic malignant melanoma. Arch. Dermatol. Res. 290: 175-180.

Miele, M.E., G. Robertson, J.H. Lee, A. Coleman, E.T. M cGary, P.B. Fisher, T.G. Lugo, and D.R. Welch. 1996. Metastasis suppressed, but tumorigenicity and local invasiveness unaffected, in the human melanoma cell line M elJuSo after introduction of human chromosomes 1 or 6 . Mol. Carcin. 15: 284-299.

Murphy, M., K. Reid, D.E. Williams, S.D. Lyman, and P.F. Bartlett. 1992. Steel factor is required for maintenance, but not differentiation, of melanocyte precursors in the neural crest. Dev. Biol. 153: 396-401.

N akamura, T., Y. Ishizaka, M. N agao, M . Hara, and T. Ishikawa. 1994. Expression of the ret proto-oncogene product in human normal and neoplastic tissues of neural crest origin. J. Pathol. 172: 255-260.

N al dini, L., E. Vigna, R.P. Narsimhan, G. Gaudino, R. Zarnegar, G.K. Michalopoulos, and P.M. Comoglio. 1991. Hepatocyte growth factor (HGF) stimulates the tyrosine kinase activity of the receptor encoded by the proto-oncogene c-M et. O ncogene 6: 501-504.

N atali, P.G., M.R. Nicotra, M.F. Di Renzo, M. Prat, A. Bigotti, R. Cavaliere, and P.M. Comoglio. 1993. Expression of the c-Met/HGF receptor in human melanocytic neoplasms: Demonstration of the relationship to malignant melanoma tumour progression. Br. J. Cancer 68: 746-750.

N ewcomb, E.W., L.S. Rao, S.S. Giknavorian, and S.Y. Lee. 1995. Alterations of multiple tumor suppressor genes p53 (17p13), and p16INK4a (9p21), and DBM (13q14) in B-cell chronic lymphocytic leukemia. Mol. Carcinog. 14: 141-146.

N guyen, L., M . Holgado-M adruga, C. M aroun, E.D. Fixman, D. Kamikura, T. Fournier, A. Charest, M.L. Tremblay, A.J. Wong, and M. Park. 1997. Association of the multisubstrate docking protein Gab1 with the hepatocyte growth factor receptor requires a functional Grb2 binding site involving tyrosine 1356. J. Biol. Chem. 272: 20811-20819.

N ishikawa, S., M. Kusakabe, K. Y oshinaga, M. Ogawa, S. Hayashi, T. Kunisada, T. Era, and T. Sakakura. 1991. In utero manipulation of coat color formation by a monoclonal antic-kit antibody: Two distinct waves of c-kit-dependency during melanocyte development. EMBO J. 10: 2111-2118.

N orris, W. 1820. A case of fungoid disease. Edinb. Med. Surg. 16: 562-565.

Ohta, M., D. Berd, M. Shimizu, H. Nagai, M. Cotticelli, M. M astrangelo, J.A. Shields, C.L. Shields, C.M. Croce, and K. Huebner. 1996. Deletion mapping of chtromosome region 9p21-p22 surrounding the CDKN 2 locus in melanoma. Int. J. Cancer 65: 762-767.

Oliner, J.D., K.W. Kinzler, P.S. Meltzer, D.L. George, and B. Vogelstein. 1992. Amplification of a gene encoding a p53associated protein in human sarcomas. Nature 358: 80-83.

Otsuka, T., H. Takayama, R. Sharp, G. Celli, W.J. LaRochelle, D. Bottaro, N. Ellmore, W. Vieira, J.W. Owens, M. Anver, and G. Merlino. 1998. c-M et autocrine activation induces development of malignant melanoma and acquisition of the metastatic phenotype. Cancer Res. 58: 5157-5167.

Park, W.S., A.O. Vortmeyer, S. Pack, P.H. Duray, R. Boni, A.A. Guerami, M.R. Emmert-Buck, L.A. Liotta, and Z. Zhuang. 1998. Allelic deletion at chromosome 9p21(p16) and $17 p 13(p 53)$ in microdissected sporadic dysplastic nevus. Hum. Pathol. 29: 127-130.

Parmiter, A.H., G. Balaban, W.H. Clark, and P.C. N owell. 1988. Possible involvement of the chromosome region 10q24-q26 in early stages of melanocytic neoplasia. Cancer Genet. Cy- 
togenet. 30: 313-317.

Pawson, T. 1995. Protein modules and signalling networks. Nature 373: 573-580.

Platz, A., J. Hansson, E. M ansson-Brahme, B. Lagerl of, S. Linder, E. Lundqvist, P. Sevigny, M. Inganas, and U. Ringborg. 1997. Screening of germline mutations in the CDKN2A and CDKN2B genes in Swedish families with hereditary cutaneous melanoma. J. Natl Cancer Inst. 89: 697-702.

Pomerantz, J., N . Schrei ber-A gus, N .J. Li egeois, A. Silverman, L. Alland, L. Chin, J. Potes, I. Orlow, H.W. Lee, C. CordonCardo, and R.A. DePinho. 1998. The IN K4a tumor suppressor gene product, p19ARF, interacts with M DM 2 and neutralizes MDM 2's inhibition of p53. Cell 92: 713-723.

Ponzetto, C., A. Bardelli, Z. Zhen, F. M aina, P. dalla Zonca, S. Giordano, A. Graziani, G. Panayotou, and P.M. Comoglio. 1994. A multifunctional docking site mediates signaling and transformation by the hepatocyte growth factor/scatter factor receptor family. Cell 77: 261-271.

Ponzetto, C., Z. Zhen, E. Audero, F. Maina, A. Bardelli, M.L. Basile, S. Giordano, R. N arsimhan, and P. Comoglio. 1996. Specific uncoupling of GRB2 from the M et receptor. Differential effects on transformation and motility. J. Biol. Chem. 271: 14119-14123.

Powell, M.B., P. Hyman, O.D. Bell, A. Balmain, K. Brown, D. Alberts, and G.T. Bowden. 1995. Hyperpigmentation and melanocytic hyperplasia in transgenic mice expressing the human T24 Ha-ras gene regulated by a mouse tyrosinase promoter. Mol. Carcin. 12: 82-90.

Prochownik, E.V., L. Eagle Grove, D. Deubler, X.L. Zhu, R.A. Stephenson, L.R. Rohr, X. Yin, and A.R. Brothman. 1998. Commonly occurring loss and mutation of the $M X I 1$ gene in prostate cancer. Genes Chromosomes Cancer 22: 295-304.

Quelle, D.E., F. Zindy, R.A. Ashmun, and C.J. Sherr. 1995. Alternative reading frames of the IN K4a tumor suppressor gene encode two unrel ated proteins capable of inducing cell cycle arrest. Cell 83: 993-1000.

Quelle, D.E., M. Cheng, R.A. Ashmun, and C.J. Sherr. 1997. Cancer-associated mutations at the IN K4a locus cancel cell cycle arrest by $\mathrm{p} 16^{\mathrm{INK} 4 \mathrm{a}}$ but not by the alternative reading frame protein p19ARF. Proc. Natl. Acad. Sci. 94: 669-673.

Ramon y Cajal, S., S. Suster, R. Halaban, E. Filvaroff, and G.P. Dotto. 1991. Induction of different morphologic features of malignant melanoma and pigmented lesions after transformation of murine melanocytes with bFGF-cDNA and $\mathrm{H}$-ras, myc, neu, and Ela oncogenes. Am. J. Pathol. 138: 349-358.

Rhodes, A.R. 1993. N eoplasms: Benign neoplasia, hyperplasias, and dysplasias of melanocytes. In Dermatology in general medicine (ed. T.B. Fitzpatrick, A.Z. Eisen, K. Wolff, I.M. Freedberg, and K.F. Austen), pp. 996-1077. McGraw-Hill, N ew York, NY.

Rigel, D.S., R.J. Friedman, and A.W. Kopf. 1996. Lifetime risk for development of skin cancer in the U.S. population: Current estimate is now 1 in 5. J. Am. Acad. Derm. 35: 10121013.

Robertson, G.P., F.B. Furnari, M .E. Miele, M.J. Glendening, D.R. Welch, J.W. Fountain, T.G. Lugo, H.S. Huang, and W.K. Cavenee. 1998. In vitro loss of heterozygosity targets the PTEN/MMAC1 gene in melanoma. Proc. Natl. Acad. Sci. 95: 9418-9423.

Rodeck, U. and M. Herlyn. 1991. Growth factors in melanoma. Cancer Metastasis Rev. 10: 89-101.

Rodrigues, G.A., M. Park, and J. Schlessinger. 1997. Activation of the JNK pathway is essential for transformation by the Met oncogene. EMBO J. 16: 2634-2645.

Royal, I. and M. Park. 1995. Hepatocyte growth factor-induced scatter of Madin-Darby canine kidney cells requires phosphatidylinositol 3-kinase. J. Biol. Chem. 270: 27780-27787.

Ruiz, A., S. Puig, M. Lynch, T. Castel, and X. Estivill. 1998. Retention of the CDKN2A locus and low frequency of point mutations in primary and metastatic cutaneous malignant melanoma. Int. J. Cancer 76: 312-316.

Rusciano, D., P. Lorenzoni, and M.M. Burger. 1995. Expression of constitutively activated hepatocyte growth factor/scatter factor receptor (c-met) in B16 melanoma cells selected for enhanced liver colonization. O ncogene 11: 1979-1987.

Russo, A.A., L. Tong, J.O. Lee, P.D. Jeffrey, and N.P. Pavletich. 1998. Structural basis for inhibition of the cyclin-dependent kinase Cdk6 by the tumour suppressor p16 ${ }^{\text {INK4a }}$. Nature 395: 237-243.

Saitoh, K., H. Takahashi, N. Sawada, and P.G. Parsons. 1994. Detection of the c-met proto-oncogene product in normal skin and tumours of melanocytic origin. J. Pathol. 174: 191199.

Schartl, M. and D. Adam. 1992. Molecular cloning, structural characterization, and analysis of transcription of the melanoma oncogene of Xiphophorus. Pigment Cell Res. (Suppl.) 2: 173-180.

Schlessinger, J. and A. Ullrich. 1992. Growth factor signal ing by receptor tyrosine kinases. Neuron 9: 383-391.

Schrei ber-Agus, N., Y. M eng, T. Hoang, H. Hou, Jr., C. Chen, R. Greenberg, C. Cordon-Cardo, H.W. Lee, R.A. DePinho, H.J. $\mathrm{Hou}$, and K. Chen. 1998. Role of M xi 1 in aging organ systems and the regulation of normal and neoplastic growth. N ature 393: 483-487.

Serrano, M., G.J. Hannon, and D. Beach. 1993. A new regulatory motif in cell-cycle control causing specific inhibition of cyclin D/CDK4. Nature 366: 704-707.

Serrano, M., H. Lee, L. Chin, C. Cordon-Cardo, D. Beach, and R.A. DePinho. 1996. Role of the INK4a locus in tumor suppression and cell mortality. Cell 85: 27-37.

Serrano, M., A.W. Lin, M.E. McCurrach, D. Beach, and S.W. Lowe. 1997. Oncogenic ras provokes premature cell senescence associated with accumulation of p53 and p16IN K4a. Cell 88: 593-602.

Sherr, C.J. 1996. Cancer cell cycles. Science 274: 1672-1676.

Shih, I.M. and M. Herlyn. 1994. Autocrine and paracrine roles for growth factors in melanoma. In Vivo. 8: 113-123.

Soriano, P. 1997. The PDGF al pha receptor is required for neural crest cell development and for normal patterning of the somites. Development 124: 2691-2700.

Soufir, N., M.F. A vril, A. Chompret, F. Demenais, J. Bombled, A. Spatz, D. Stoppa-Lyonnet, J. Benard, and B. Bressac-de Paillerets. 1998. Prevalence of p16 and CDK4 germline mutations in 48 melanoma-prone families in France. The French Familial M elanoma Study Group. Hum. Mol. Genet. 7: 209-216.

Speaks, S.L., W.G. Sanger, A.S. Masih, D.S. Harrington, M. Hess, and J.O. Armitage. 1992. Recurrent abnormalities of chromosome bands 10q23-25 in non-Hodgkin's Iymphoma. Genes Chromosomes Cancer 5: 239-243.

Steel, K.P., D.R. Davidson, and I.J. Jackson. 1992. TRP-2/DT, a new early melanoblast marker, shows that steel growth factor (c-kit ligand) is a survival factor. Development 115: 1111-1119.

Stephenson, D.A., M. Mercola, E. Anderson, C.Y. Wang, C.D. Stiles, D.F. Bowen-Pope, and V.M. Chapman. 1991. Platel etderived growth factor receptor al pha-subunit gene (Pdgfr $\alpha)$ is del eted in the mouse patch $(\mathrm{Ph})$ mutation. Proc. Natl. Acad. Sci. 88: 6-10.

Stott, F., S.A. Bates, M. James, B.B. M cConnell, M. Starborg, S. 
Brookes, I. Palmero, E. Hara, K.H. Vousden, and G. Peters. 1998. The alternative product from the human CDKN2A locus, p14 ${ }^{\mathrm{ARF}}$, partici pates in a regulatory feedback loop with p53 and MDM2. EMBO J. 17: 5001-5014.

Takayama, H., W.J. La Rochelle, M. Anver, D.E. Bockman, and G. M erlin. 1996. Scatter factor/hepatocyte growth factor as a regulator of skeletal muscle and neural crest development. Proc. Natl. Acad. Sci. 93: 5866-5871.

Takayama, H., W.J. LaRochelle, R. Sharp, T. Otsuka, P. Kriebel, M. Anver, S.A. Aaronson, and G. Merlino. 1997. Diverse tumorigenesis associated with aberrant development in mice overexpressing hepatocyte growth factor/scatter factor. Proc. Natl. Acad. Sci. 94: 701-706.

Taniguchi, M., T. Iwamoto, I. Nakashima, A. Nakayama, M. Ohbayashi, M. M atsuyama, and M. Takahashi. 1992. Establishment and characterization of a malignant melanocytic tumor cell line expressing the ret oncogene. Oncogene 7: 1491-1496.

Trent, J.M. 1991. Cytogenetics of human malignant melanoma. Cancer Metastasis Rev. 10: 103-113.

Trent, J.M., E.J. Stanbridge, H.L. M cBride, E.U. M eese, G. Casey, D.E. Araujo, C.M. Witkowski, and R.B. Nagle. 1990. Tumorigenicity in human mel anoma cell lines controlled by introduction of human chromosome 6. Science 247: 568571.

Tsao, H., X. Zhang, E. Benoit, and F.G. Haluska. 1998. Identification of PTEN/MMACl al terations in uncultured melanomas and melanoma cell lines. Oncogene 16: 3397-3402.

Tucker, M.A., A. Hal pern, E.A. Holly, P. Hartge, D.E. Elder, R.W. Sagebiel, D. Guerry IV, and W.H. Clark. 1997. Clinically recognized dysplastic nevi. A central risk factor for cutaneous melanoma. J. Am. Med. Assoc. 277: 1439-1444.

van't Veer, L.J., B.M. Burgering, R. Versteeg, A.J. Boot, D.J. Ruiter, S. Osanto, P.I. Schrier, and J.L. Bos. 1989. N -ras mutations in human cutaneous melanoma from sun-exposed body sites. Mol. Cell. Biol. 9: 3114-3116.

Wagner, S.N., H.M. Ockenfels, C. Wagner, H. Hofler, and M. Goos. 1995. Ras gene mutations: A rare event in nonmetastatic primary malignant melanoma. J. Invest. Dermatol. 104: 868-871.

Wagner, S.N., C. Wagner, L. Briedigkeit, and M. Goos. 1998. Homozygous deletions of the p16INK4a and the p15INK4B tumour suppressor genes in a subset of human sporadic Cutaneous malignant melanoma. Br. J. Dermatol. 138: 13-21.

Wang, Y. and D. Becker. 1997. Antisense targeting of basic fibroblast growth factor and fibroblast growth factor receptor-1 in human melanomas blocks intratumoral angiogenesis and tumor growth. Nature Med. 3: 887-893.

Wehrle-Haller, B. and J.A. Weston. 1995. Soluble and cell-bound forms of steel factor activity play distinct roles in melanocyte precursor dispersal and survival on the lateral neural crest migration pathway. Development 121: 731-742.

Weidner, K.M., M. Sachs, D. Riethmacher, and W. Birchmeier. 1995. Mutation of juxtamembrane tyrosine residue 1001 suppresses loss-of-function mutations of the met receptor in epithelial cells. Proc. Natl. Acad. Sci. 92: 2597-2601.

Weidner, K.M., S. Di Cesare, M. Sachs, V. Brinkmann, J. Behrens, and W. Birchmeier. 1996. Interaction between Gabl and the c-M et receptor tyrosine kinase is responsible for epithelial morphogenesis. Nature 384: 173-176.

Weiss, A. and J. Schlessinger. 1998. Switching signals on and off by receptor dimerization. Cell 94: 277-280.

Welch, D.R. and S.F. Goldberg. 1997. Molecular mechanisms controlling human melanoma progression and metastasis. Pathobiology 65: 311-330.
Welch, D.R., P. Chen, M.E. Miele, C.T. McGary, J.M. Bower, E.J. Stanbridge, and B.E. Weissman. 1994. Microcell-mediated transfer of chromosome 6 into metastatic human C8161 melanoma cells suppresses metastasis but does not inhibit tumorigenicity. O ncogene 9: 255-262.

Wilson, R.E., T.P. Dooley, and I.R. Hart. 1989. Induction of tumorigenicity and lack of in vitro growth requirement for 12-O-tetradecanoylphorbol-13-acetate by transfection of murine melanocytes with v-Ha-ras. Cancer Res. 49: 711716.

Wittbrodt, J., D. Adam, B. Malitschek, W. Maueler, F. Raulf, A. Telling, S.M. Robertson, and M. Schartl. 1989. Novel putative receptor tyrosine kinase encoded by the melanoma-inducing Tu locus in Xiphophorus. Nature 341: 415-421.

Witte, O.N. 1990. Steel locus defines new multipotent growth factor. Cell 63: 5-6.

Wolfel, T., M. Hauer, J. Schneider, M. Serrano, C. Wolfel, E. Klehmann-Hieb, P.E. De, T. Hankeln, Z.B.H. Meyer, and D. Beach. 1995. A p16IN K4a-insensitive CDK4 mutant targeted by cytolytic $T$ lymphocytes in a human melanoma. Science 269: 1281-1284.

Yasuda, H., H. Kobayashi, A. Ohkawara, and N. Kuzumaki. 1989. Differential expression of ras oncogene products among the types of human melanomas and melanocytic nevi. J. Invest. Dermatol. 93: 54-59.

Yayon, A., Y.S. Ma, M. Safran, M. Klagsbrun, and R. Halaban. 1997. Suppression of autocrine cell proliferation and tumorigenesis of human melanoma cells and fibroblast growth factor transformed fibroblasts by a kinase-deficient FGF receptor 1: Evidence for the involvement of Src-family kinases. Oncogene 14: 2999-3009.

Zakut, R., R. Perlis, S. Eliyahu, Y. Yarden, D. Givol, S.D. Lyman, and R. Halaban. 1993. KIT ligand (mast cell growth factor) inhibits the growth of KIT-expressing melanoma cells. O ncogene 8: 2221-2229.

Zhang, Y., Y. Xiong, and W.G. Yarbrough. 1998. ARF promotes MDM 2 degradation and stabilizes p53: ARF-INK4a locus del etion impairs both the Rb and $\mathrm{p} 53$ tumor suppressor pathways. Cell 92: 725-734.

Zuo, L., J. Weger, B. Yang, A.M. Goldstein, M.A. Tucker, G.J. Walker, N. Hayward, and N.C. Dracopoli. 1996. Germline mutations in the p16 ${ }^{\text {INK4a }}$ binding domain of CDK4 in familial melanoma. Nature Genet. 12: 97-99. 


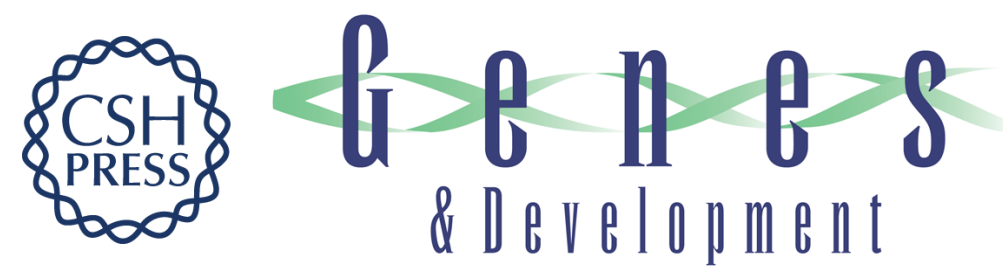

\section{Malignant melanoma: modern black plague and genetic black box}

Lynda Chin, Glenn Merlino and Ronald A. DePinho

Genes Dev. 1998, 12:

Access the most recent version at doi:10.1101/gad.12.22.3467

References This article cites 159 articles, 47 of which can be accessed free at: http://genesdev.cshlp.org/content/12/22/3467.full.html\#ref-list-1

License

Email Alerting Receive free email alerts when new articles cite this article - sign up in the box at the top Service right corner of the article or click here.

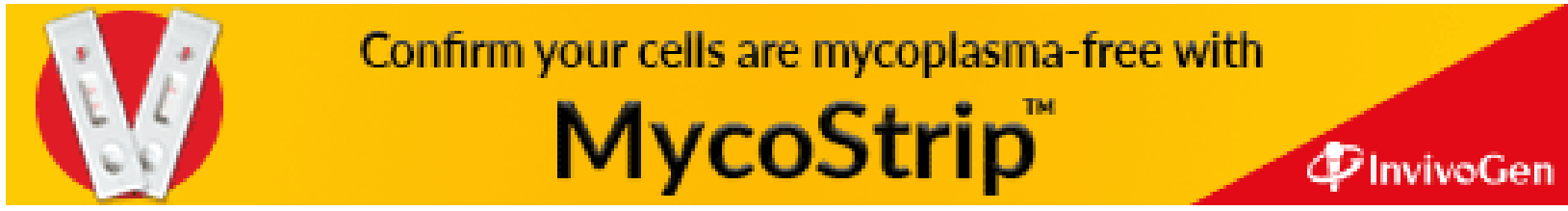

